\title{
NETO1 Guides Development of Glutamatergic Connectivity in the Hippocampus by Regulating Axonal Kainate Receptors
}

\author{
Ester Orav, ${ }^{1}$ [D Tsvetomira Atanasova, ${ }^{1}{ }^{\circledR}$ Alexandra Shintyapina, ${ }^{1}$ Sebnem Kesaf, ${ }^{1}$ Michela Kokko, ${ }^{1}$ \\ Juha Partanen, ${ }^{2}$ Tomi Taira, ${ }^{1,3}$ and 1 Sari E. Lauri ${ }^{1,2}$
}

DOI:http://dx.doi.org/10.1523/ENEURO.0048-17.2017

${ }^{1}$ Neuroscience Center, University of Helsinki, Helsinki Fl-00014, Finland, ${ }^{2}$ Department of Biosciences, University of Helsinki, Helsinki $\mathrm{Fl}-00014$, Finland, and ${ }^{3}$ Department of Veterinary Biosciences, University of Helsinki, Helsinki Fl-00014, Finland

\begin{abstract}
Kainate-type glutamate receptors (KARs) are highly expressed in the developing brain, where they are tonically activated to modulate synaptic transmission, network excitability and synaptogenesis. NETO proteins are auxiliary subunits that regulate biophysical properties of KARs; however, their functions in the immature brain are not known. Here, we show that NETO1 guides the development of the rodent hippocampal CA3-CA1 circuitry via regulating axonal KARs. NETO deficiency reduced axonal targeting of most KAR subunits in hippocampal neurons in a subtype independent manner. As an interesting exception, axonal delivery of GluK1c was strongly and selectively impaired in the Neto $1^{-1-}$, but not $\mathrm{Neto}^{-1-}$, neurons. Correspondingly, the presynaptic GluK1 KAR activity that tonically inhibits glutamate release at immature CA3-CA1 synapses was completely lost in the absence of NETO1 but not NETO2. The deficit in axonal KARs at $\mathrm{Neto}^{-1-}$ neurons resulted in impaired synaptogenesis and perturbed synchronization of CA3 and CA1 neuronal populations during development in vitro. Both these $\mathrm{Neto1}^{-1-}$ phenotypes were fully rescued by overexpression of GluK1c, emphasizing the role of NETO1/KAR complex in development of efferent connectivity. Together, our data uncover a novel role for NETO1 in regulation of axonal KARs and identify its physiological significance in development of the CA3-CA1 circuit.
\end{abstract}

Key words: auxiliary subunit; development; GluK1; hippocampus; kainate receptor; NETO

\section{Significance Statement}

Kainate-type glutamate receptors (KARs) are highly expressed in the developing brain where they modulate synaptic transmission and synaptogenesis. NETO proteins act as auxiliary subunits for KARs; however, their functions at the immature circuit are not known. Using a combination of cell biology and electrophysiology in Neto1- and Neto2-deficient mouse models, we show that NETO proteins regulate axonal delivery of KARs. The deficit in axonal KAR at immature Neto $1^{-1-}$ neurons manifested as loss of presynaptic KAR activity and resulted in impaired synaptogenesis and perturbed development of the hippocampal CA3-CA1 circuit. These findings suggest novel roles for the NETO auxiliary subunits in orchestrating development and refinement of synaptic connectivity, a process increasingly implicated in developmentally originating neurologic disorders.

\section{Introduction}

Ionotropic glutamate receptors are key signaling elements mediating and modulating fast excitatory neurotransmission

Received February 8, 2017; accepted June 13, 2017; First published June 20, 2017.

The authors declare no competing financial interests. in the brain. During development, glutamate receptors contribute to refinement of synaptic connectivity by triggering signals that regulate synaptic structure and function in 
response to patterned neuronal activity. In particular, the kainate-type glutamate receptors (KAR) are highly expressed in developing neuronal networks and have been implicated both in synaptogenesis (Tashiro et al., 2003; Marchal and Mulle, 2004; Vesikansa et al., 2007; Lanore et al., 2012; Sakha et al., 2016,) and activity-dependent plasticity at immature synapses (Lauri et al., 2006; Sallert et al., 2009; Clarke et al., 2014).

KARs are tetrameric receptors composed of five different subunits, GluK1-GluK5. In the hippocampus, GluK1 subunit containing receptors act presynaptically to modulate glutamate release (Lauri et al., 2001; Clarke et al., 2014; reviewed by Pinheiro and Mulle, 2008) and at interneurons, to regulate GABAergic transmission (reviewed by Lerma and Marques, 2013; Akgül and McBain, 2016). During the developmental fine-tuning of the circuitry, GluK1 subunit containing KARs are tonically activated by ambient extracellular glutamate (Lauri et al., 2005, 2006; Segerstråle et al., 2010). At immature CA3-CA1 synapses, tonically active presynaptic KARs inhibit glutamate release probability and, consequently, account for substantial frequency-dependent facilitation of synaptic transmission (Lauri et al., 2006). The frequency-dependent tuning of the transmission via presynaptic KARs is thought to be critical for appropriate development of the CA3-CA1 circuitry (Vesikansa et al., 2007; Hanse et al., 2009).

NETO proteins are auxiliary subunits that critically modulate the biophysical properties of KARs (reviewed by Copits and Swanson, 2012; Tomita and Castillo, 2012). Their roles in modulating the physiological functions of KARs have been studied at mossy fiber synapses in the area CA3, where NETO1 is responsible for the slow kinetics of postsynaptic KAR-mediated currents (Straub et al., 2011; Tang et al., 2011). In addition, both NETO1 and NETO2 may regulate synaptic recruitment of KARs (Copits et al., 2011; Tang et al., 2011, 2012; Wyeth et al., 2014; Sheng et al., 2015; Palacios-Filardo et al., 2016), although the exact molecular mechanisms of the NETOdependent targeting of various KAR subunits remain unclear.

Here, we have studied the roles of NETO1/2 proteins in the developing glutamatergic circuitry. We show that both NETO1 and NETO2 are expressed in the developing hippocampus and that NETO1, but not NETO2, regulates

data; E.O. and S.E.L. wrote the paper.

This work was supported by the Academy of Finland, Jane and Aatos Erkko Foundation, Sigrid Juselius Foundation, and the Doctoral Program in Brain and Mind.

Acknowledgements: We thank Roderick Mclnnes and David Ng (McGill University, Montreal, Canada) for providing the $\mathrm{Neto}^{-{ }^{-1}}$ and Neto2 ${ }^{-1-}$ mouse lines and David $\mathrm{Ng}$ for commenting this manuscript. We also thank Kirsi Kolehmainen, Seija Lagas, Erja Huttu, and Outi Kostia for excellent technical help and Zoya Kharybina for writing the MatLab script for STTC analysis.

Correspondence should be addressed to Sari E. Lauri, Department of Biosciences and Neuroscience Center, PO Box 65 (Viikinkaari 1), 00014 University of Helsinki, Finland, E-mail: sari.lauri@helsinki.fi.

DOI:http://dx.doi.org/10.1523/ENEURO.0048-17.2017

Copyright (C) 2017 Orav et al.

This is an open-access article distributed under the terms of the Creative Commons Attribution 4.0 International license, which permits unrestricted use, distribution and reproduction in any medium provided that the original work is properly attributed. axonal and presynaptic KARs at the CA3-CA1 circuit. NETO1 deficiency resulted in impaired synaptogenesis and disrupted synchronization of the CA3-CA1 neuronal populations. Both these Neto $1^{-/-}$phenotypes were fully rescued by overexpression of GluK1c KAR subunit, consistent with a role of NETO1/KAR complex in development of efferent connectivity (Lauri et al., 2006; Vesikansa et al., 2012; Sakha et al., 2016).

\section{Materials and Methods}

\section{Animals}

Experiments were performed using wild-type (WT), $\mathrm{Neto}^{-1-}$, and $\mathrm{Neto}^{-/-}$(C57BI/6NCrl) mice ( $\mathrm{Ng}$ et al., 2009; Tang et al., 2011) of either sex. All experiments with animals were done in accordance with the University of Helsinki Animal Welfare Guidelines.

\section{RT-PCR}

Total RNA was purified from hippocampal tissue or dispersed WT hippocampal neurons using RNeasy Micro kit (QIAGEN) with an on-column DNase digestion step. cDNA was synthesized from $1 \mu \mathrm{g}$ of total RNA using RevertAid First Strand cDNA synthesis kit (Thermo Scientific) with oligo $(\mathrm{dT})_{18}$ primer. Real-time quantitative PCR (RT-qPCR) was performed using CFX96 Maxima SYBR Green qPCR Master Mix (Thermo Scientific) according to manufacturer's recommendation and Real-Time PCR Detection System (Bio-Rad). All samples were analyzed in triplicate using Gadph as a reference gene and primers listed in Table 1. Initial copy number of a sample was obtained by relating the $\mathrm{Ct}$ of the sample to a standard curve plot. Relative quantification of Neto expression at different developmental stages was analyzed using standard $2^{-\mathrm{ddCt}}$ method. The values are expressed as percentage $(\%)$ of postnatal day $(\mathrm{P}) 4 \quad(100 \%=$ gene expression level at P4).

Reverse transcription (RT-PCR) was performed using Phusion High-Fidelity DNA polymerase (F-530L, Thermo Scientific) according to manufacturer's recommendation to test Neto1 and Neto2 expression in the dispersed hippocampal neuron culture. PCR products were visually confirmed by gel electrophoresis.

\section{In situ hybridization (ISH)}

ISH was conducted on $5-\mu \mathrm{m}$-thick paraffin sections as described previously (Wilkinson and Green, 1990) using digoxigenin-labeled antisense and sense RNA probes against Neto1 and Neto2 (Table 2). TSA-Plus Cyanine3/ Fluorescein System (PerkinElmer) was used to visualize ISH signal, followed with a standard DAPI staining. The specificity of reaction conditions was tested using the sense RNA probes. At least three sections from two independent experiments were analyzed for each group. Samples were imaged using a Zeiss Axioimager M2 microscope with $20 \times$ objective and Axiocam HRc camera. For analysis, images with equal exposure time were imported to ImageJ software and the mean optical density of the in situ staining was normalized to the number of DAPI-positive cells in the analyzed area. 
Table 1. RT-qPCR primers

\begin{tabular}{lll}
\hline Target & Forward & Reverse \\
Neto1 & TCATAGAAGCTGCCCCAAGG & AAGCCAAAGGGTCCATCTCG \\
Neto2 & TTTGAAGCTGCTCCTCGTC & TCCAAGTGATCAAACCGGCA \\
Gapdh & CAGTGCCAGCCTCGTCTCATA & TGGTAACCAGGCGTCCGATA \\
\hline
\end{tabular}

Table 2. Primers used for RT-PCR and for synthesis of ISH probes against Neto1 and Neto2

\begin{tabular}{lll}
\hline Target & Forward & Reverse \\
Neto1 & TGAGTTGAGATGGGCGGCC & ACTGGTGTTGGCAGCTGAT \\
Neto2 & CTGATGGAATAGTGCGGTCT & GATCGTCCCATGAGTCTTCG \\
& CAACGACCCCTTCATTGACC & AGTGATGGCATGGACTGTGG \\
\hline
\end{tabular}

\section{Plasmid generation and lentiviral vectors}

Epitope tagged plasmid constructs for NETO1 and NETO2 were generated as described previously (Vesikansa et al., 2012). Briefly, Neto1 and Neto2 were amplified by PCR from rat brain cDNA and inserted into pTZ57R/T cloning vector (Thermo Scientific), and an inframe HA tag was added to C terminus of NETO1 and 2 from Addgene plasmid 10792 (a gift of William Sellers). The epitope tagged constructs were subcloned into lentiviral transfer vector under a CMV promoter. Plasmids encoding various KAR subunits were described previously (Vesikansa et al., 2012; Sakha et al., 2016). The lentiviral particles were prepared as described previously (Vesikansa et al., 2012).

\section{Cell culture}

Dispersed hippocampal neuron culture was prepared from P0 to P2 old mice pups. Hippocampi were isolated, digested with papain $(500 \mu \mathrm{g} / \mathrm{ml}$, Sigma) and triturated. Cells were plated with a density of $10,000 \mathrm{cells} / \mu \mathrm{m}$ on poly-L-lysin (Sigma) coated 24-well plates containing glass coverslips and grown in Neurobasal A (Gibco) medium containing 2\% B27 supplement, $0.5 \mathrm{mM}$ L-glutamine, and 1\% penicillin/streptomycin (all from Life Technologies). At $3 \mathrm{~d}$ in vitro (DIV3), the cell cultures were infected with lentiviral vectors (Table 3 ) and fixed at DIV14 using 4\% PFA in PBS.

\section{Immunofluorescence}

For immunostainings, fixed neurons were permeabilized with $0.2 \%$ Triton X-100 and incubated with PBS based blocking solution containing $5 \%$ goat serum, $1 \%$ bovine serum albumin (BSA), $0.1 \%$ gelatin, $0.1 \%$ Triton $\mathrm{X}-100$, and $0.05 \%$ Tween 20 . Primary antibodies [guinea pig anti-synaptophysin (1:2000; 101004, Synaptic sys-

Table 3. Lentiviral constructs used in this study

\begin{tabular}{llll}
\hline Protein & Promoter & Tag & Tag location \\
GFP & CMV & - & - \\
GluK1b(Q) & CMV & Flag & $\mathrm{N}$ terminus, after signal sequence \\
GluK1c(Q) & CMV & Flag & $\mathrm{N}$ terminus, after signal sequence \\
GluK2(Q) & CMV & myc & $\mathrm{N}$ terminus, after signal sequence \\
GluK4 & CMV & myc & $\mathrm{N}$ terminus, after signal sequence \\
GluK5 & CMV & myc & $\mathrm{N}$ terminus, after signal sequence \\
NETO1 & CMV & HA & C terminus \\
NETO2 & CMV & HA & C terminus
\end{tabular}

tems), mouse anti-flag (1:1000; F1804, Sigma), rabbit anti-myc (1:1000; 06-549, Millipore), chicken anti-MAP2 (1:8000; AB5543, Millipore), and mouse anti-HA (1:1000; MMS-101R, Covance)] were diluted in a solution containing $1 \%$ BSA and $0.1 \%$ gelatin. The following secondary antibodies were used: goat anti-mouse Alexa Fluor 647 (1:2000; A21236, Life Technologies), goat anti-rabbit Alexa Fluor 647 (1:2000; A21245, Life Technologies), goat anti-guinea pig Alexa Fluor 568 (1:2000; A11075, Life Technologies), and goat anti-chicken Alexa Fluor 405 (1: 500; ab175674, Abcam). The stained samples were mounted on microscope slides using Prolong Gold antifade reagent (P36934, Life technologies). Confocal images were acquired using a LSM Zeiss 710 confocal microscope (alpha Plan-Apochromat 63×/1.46 OilKorr M27 objective).

\section{Image analysis}

NETO-HA (blue; Alexa Fluor 647) and synaptophysin (red, Alexa Fluor 568) colocalization was analyzed by calculating Pearson's correlation coefficient (PCC) using Coloc2 plugin in Fiji (ImageJ) software. PCC was calculated for each z-stack separately. Axonal processes were identified using MAP2 staining. Cells exhibiting one MAP2 negative axon and several MAP2-positive dendrites were included in the analysis. Axonal intensity of the staining was measured using SynD/MATLAB (Schmitz et al., 2011) and normalized to intensity at the cell soma. For Syn puncta counting, only isolated axons without MAP2positive dendritic contact were included in the analysis. Synaptophysin puncta (minimum size, $0.07 \mu \mathrm{m}^{2}$ ) were counted using SynD and presented per $100 \mu \mathrm{m}$ of axon length. All images were coded and analyzed in a blind fashion. Brightness/contrast and levels were adjusted in Photoshop for final figures.

\section{Organotypic slice culture}

For preparation of organotypic cultures, hippocampi were dissected from P6-P7 day old WT or Neto $1^{-1-}$ mice in ice cold Gey's balanced salt solution (GBSS; Sigma) supplemented with glucose $(6.5 \mathrm{mg} / \mathrm{ml})$. The hippocampi were mounted on $2 \%$ liquid agarose and $400-\mu \mathrm{m}$-thick slices were cut using a Mcllwain tissue chopper. After $1 \mathrm{~h}$ recovery in carbogenated $\left(95 \% \mathrm{O}_{2}\right.$ and $\left.5 \% \mathrm{CO}_{2}\right) \mathrm{GBSS}$, the slices were transferred to MED64-probe plates (MEDP515A, Alpha Med Scientific) coated with polyethylenimine solution $(0.1 \% \mathrm{PEI}$ in $25 \mathrm{mM}$ borate buffer) or onto 
Millicell-CM 0.4- $\mu \mathrm{m}$ membrane inserts (Millipore, Bedford) in six-well plates. The slices were cultivated in $250 \mu \mathrm{l}$ of culture medium [Neurobasal A (Gibco), 2\% B27supplement (Gibco), 2 mM L-glutamine, and chloramphenicol] on MED64 probes or $1.2 \mathrm{ml}$ of culture medium on the membrane inserts. Cultures were maintained in humidified $\mathrm{CO}_{2}$ incubator $\left(+35^{\circ} \mathrm{C}\right)$, where MED64 probes were kept on a rocking stage. The culture media was changed every second day. In some of the WT and Neto $1^{-1-}$ slices, lentiviral particles encoding for GFP and GluK1c under separate syn1 promoters (Vesikansa et al., 2012) or GFP only were injected into the CA3 pyramidal region at DIV1. Slices grown on MED64 probes were subjected to microelectrode array recordings, while slices grown on membrane inserts were used for miniature EPSC (mEPSC) recordings at DIV5-DIV7. After recordings, the slices were fixed with $4 \%$ PFA and imaged to visualize slice morphology and infection rate in CA3 pyramidal layer.

\section{Electrophysiology}

Acute parasagittal hippocampal sections (400 $\mu \mathrm{m})$ were prepared from brains of neonatal (P4-P6) or juvenile (P14P16) mice using standard methods (Lauri et al., 2006). Whole-cell patch clamp recordings were done from CA1 pyramidal neurons in acute or cultured slices using Csbased intracellular solution containing $130 \mathrm{mM} \mathrm{CsMeSO}_{4}$, 10 mM HEPES, 0.5 mM EGTA, 4 mM Mg-ATP, 0.3 mM Na-GTP, 5 mM QX-314, and 8 mM NaCl; 285 mOsm, pH 7.2. Uncompensated series resistance (Rs $<30 \mathrm{MOhm})$ was monitored, and cells were discarded if Rs varied more that $20 \%$. EPSCs were evoked by afferent stimulation with a basal frequency of $0.05 \mathrm{~Hz}$ in the presence of picrotoxin $(100 \mu \mathrm{M})$ and D-AP5 $(50 \mu \mathrm{M})$ to antagonize $\mathrm{GABA}_{\mathrm{A}^{-}}$and NMDA receptors, respectively. For mEPSC recordings, $1 \mu \mathrm{M}$ TTX was also included. Data were collected using Axoscope 9.2 (Molecular Devices) or WinLTP software (Anderson and Collingridge, 2007). mEPSCs were analyzed with MiniAnalysis 6.0.3 program (Synaptosoft). Events were verified visually, and events with amplitude less than three times the baseline rms noise level were rejected. For time-course plots, detected events were calculated in 120-s bins. Evoked EPSC amplitude was analyzed using WinLTP. Decay time of the AMPA currents was calculated from $90-37 \%$ of the peak amplitude using the Mini Analysis Program 6.0.7.

\section{Microelectrode array recordings}

The spontaneous activity of the slices was recorded for a 15-min period at DIV2 and/or DIV6 using the MED 64-amplifier (MED-A64HE1, Alpha MED Scientific). The data were collected with the Mobius Software (Alpha MED Scientific) using a low cut frequency of $0.1 \mathrm{~Hz}$, high cut frequency of $5000 \mathrm{~Hz}$ and a sampling rate of $20 \mathrm{kHz}$. For analysis, the data were exported to LabView environment and filtered using Savitzky-Golay filter (half-width $=10$ side points). Spikes were detected using the LabView Peak Detector algorithm (quadratic fit on a window of width $=3$ points). The spike detection threshold was calculated using the median absolute deviation-based method (Chan et al., 2008) with a multiplicative factor $p=$
3.5 , and verified visually. Bursts were defined as a sequence of spikes with a minimum of three spikes with a maximum interspike interval of $10 \mathrm{~ms}$. For calculation of spike time tiling coefficient (STTC), at least two CA3 and CA1 channel pairs separated by at least $300 \mu \mathrm{m}$ were selected for each slice. Time stamps for detected spikes from 10 s period with clearly visible activity and without long (>300 ms) bursts were exported to MatLab. STTC was calculated as described previously (Cutts and Eglen, 2014), and the values for all the channel pairs in each slice were averaged and considered as $n=1$.

\section{Statistical analysis}

All statistics were calculated on raw (not normalized) data using Sigma Plot software. Shapiro-Wilk test was used to test for normal distribution and Student's paired $t$ test, one-way ANOVA with Holm-Sidak post hoc comparison or Kruskal-Wallis test was then used accordingly. All data are presented as mean \pm SEM; $p<0.05$ was considered statistically significant. In figures, the significance levels are indicated by asterisks as follows: $* p<$ $0.05, * * p<0.01, * * * p<0.001$.

\section{Results}

\section{Neto1 and Neto2 are expressed in the neonatal hippocampus and may localize to presynaptic release sites}

The expression of NETO proteins has been characterized in the adult brain, where NETO1 is strongly expressed in hippocampal CA3 pyramidal neurons (Michishita et al., 2003, 2004; Ng et al., 2009; Straub et al., 2011), whereas NETO2 is predominant in most brain regions except the hippocampus (Straub et al., 2011). As expression of both Neto1 and Neto2 in brain is developmentally regulated (Michishita et al., 2004), we first used RT-qPCR to quantify the expression of Neto1 and Neto2 mRNAs in hippocampus during early postnatal development. At P4, both Neto1 and Neto2 were expressed in hippocampus (estimated copy numbers $929 \pm 87$ and $1517 \pm 106 / 0.1 \mu \mathrm{g}$ of RNA for Neto1 and Neto2 transcripts, respectively, $n=3$ for both groups, $p=0.005$ ). During development, Neto 1 expression was strongly upregulated, in contrast to Neto2, which was downregulated, resulting in prevalent expression of Neto1 in the juvenile (P14) and adult (P50) hippocampus (Fig. 1A,B). ISH detected both Neto1 and Neto2 in CA3 pyramidal neurons at P4 (Fig. $1 C$, see Fig. $1 B$ for characterization of the ISH probes). Neto2 was also expressed in the principal cells of other hippocampal regions, whereas the level of Neto1 in CA1 pyramidal neurons and dentate granule cells was low, similar to that observed previously in the adult hippocampus (Michishita et al., 2003; Ng et al., 2009; Straub et al., 2011). Later in development (P14), Neto2 expression remained in CA3 but was low in DG and CA1, while Neto 1 expression in CA3 region was strongly upregulated (Fig. 1C,D). In addition to pyramidal neurons, Neto1 was strongly expressed in cell bodies in stratum radiatum, putatively representing GABAergic interneurons. 
A

C

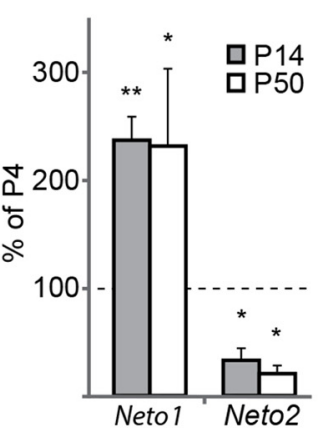

B

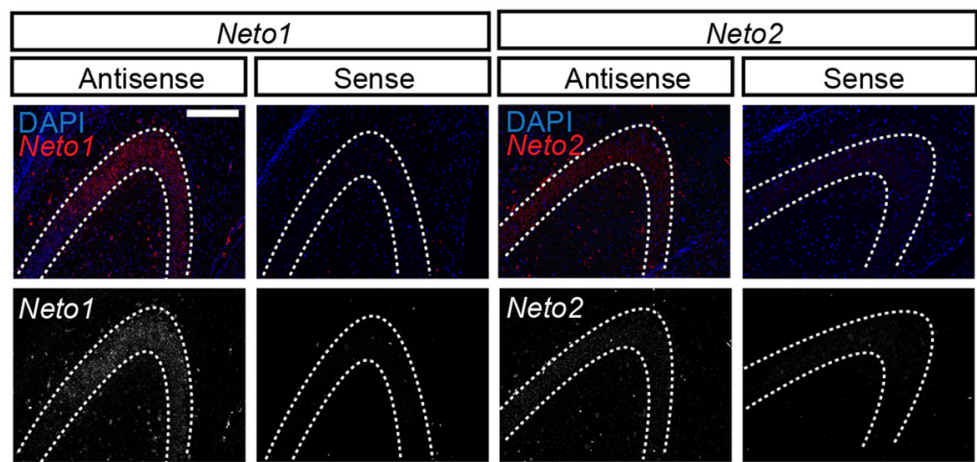

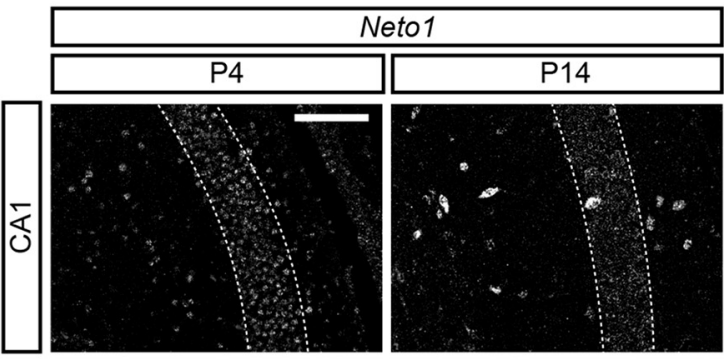
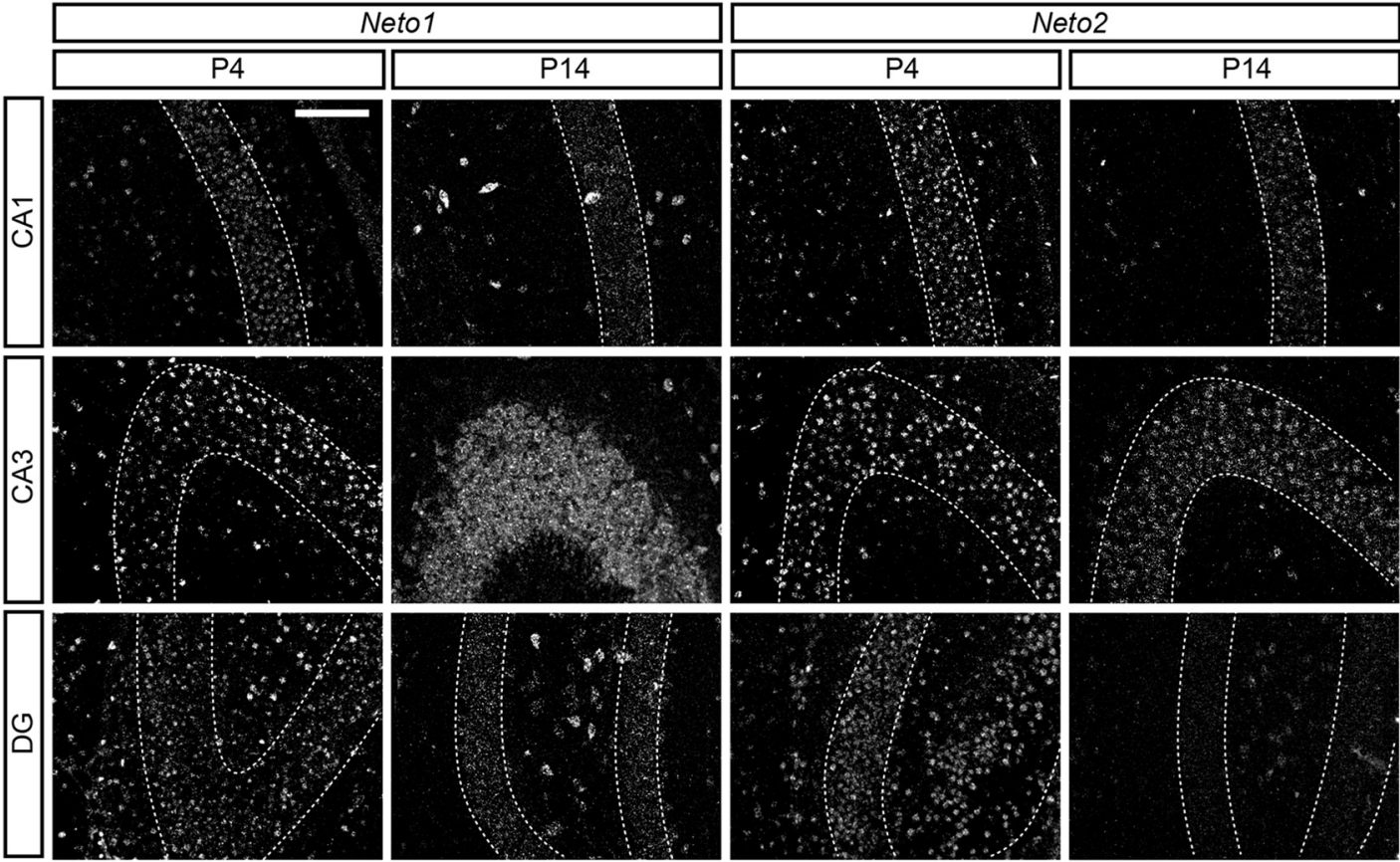

D
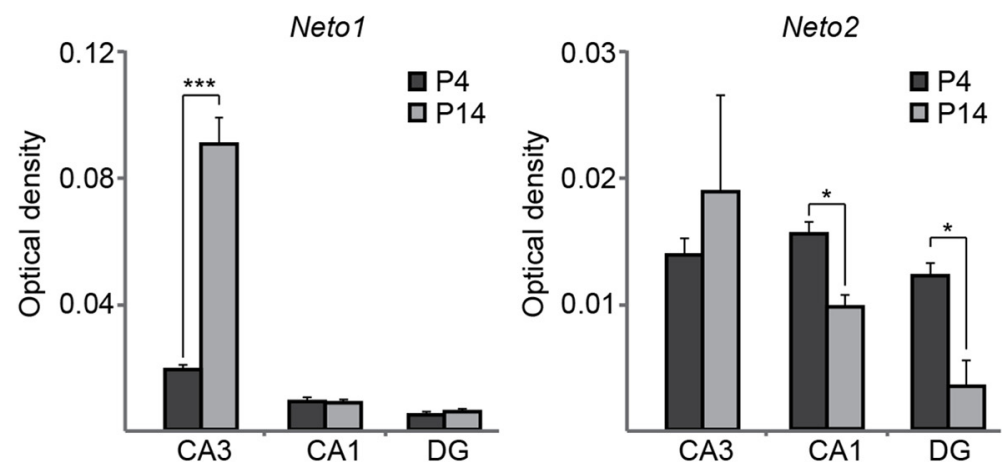

Figure 1. Developmental expression pattern of Neto1 and Neto2 in the hippocampus. $\boldsymbol{A}$, RT-qPCR analysis of Neto1 and Neto2 mRNA expression in the hippocampus. Data from three independent samples/group is represented as a percentage of the level at P4. $\boldsymbol{B}$, Example images showing staining with sense and antisense RNA probes against Neto1 and Neto2 in hippocampal sections. For analysis, the intensity of the ISH stain (red) is normalized to the number of cells within the analyzed region, identified with the DAPI stain (blue; upper row). The lower panels show the ISH stain as grayscale image. Dashed lines delineate the principal cell body layer. Scale bar, $100 \mu \mathrm{m}$. C. Example images illustrating the ISH with antisense Neto1 and Neto2 probes at P4 and P14 hippocampal sections. Dashed lines show the principal cell layer. Scale bar, $100 \mu \mathrm{m}$. $\boldsymbol{D}$, Quantified data on the mean intensity of the ISH stain for Neto1 and Neto2 in areas CA1, CA3, and DG at P4 and P14 ( $n=3-4$ samples/group). 
A
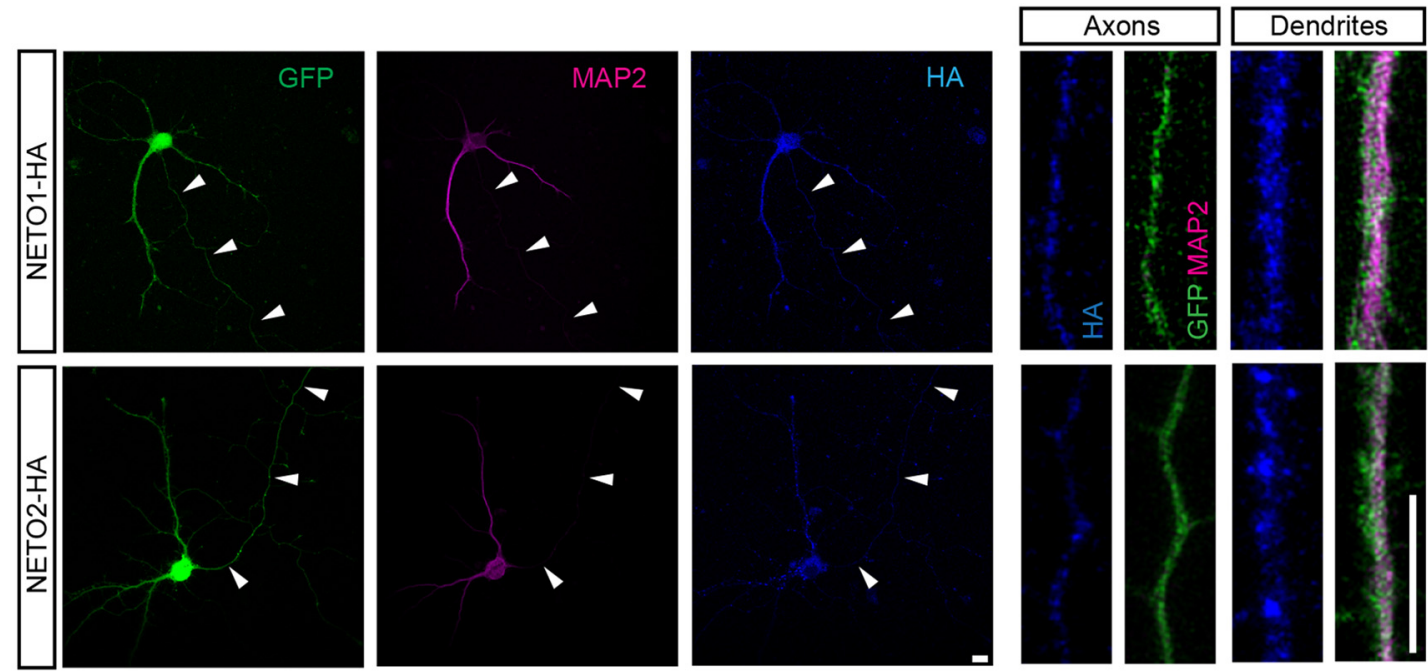

B

C
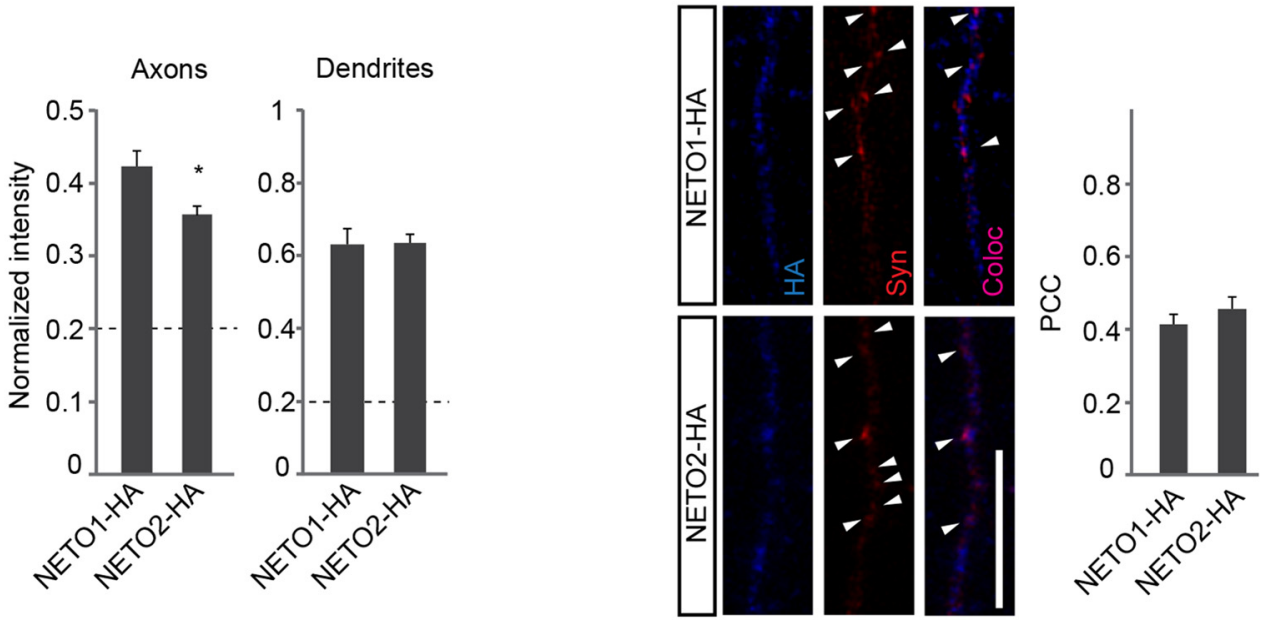

Figure 2. Subcellular localization of recombinant NETO proteins in hippocampal neurons. $\boldsymbol{A}$, Example images of hippocampal neurons expressing recombinant NETO1-HA and NETO2-HA (blue). MAP2 (purple) negative axons are marked with arrowheads. Cell morphology is visualized with GFP (green) expression. Scale bar, $10 \mu \mathrm{m}$. B, Quantified data demonstrating delivery of lentivirally expressed NETO1-HA and NETO2-HA (blue) to MAP2-positive (purple) dendritic (NETO1-HA $n=31$, NETO2-HA $n=39$ ) and MAP2-negative axonal (NETO1-HA $n=27$, NETO2-HA $n=26$ ) processes in cultured hippocampal neurons. For quantification, the signal intensity in the neurites is normalized to the soma intensity. Scale bar, $10 \mu \mathrm{m}$. $\boldsymbol{C}$, Example images and quantified data demonstrating colocalization of lentivirally expressed NETO1-HA $(n=27)$ and NETO2-HA $(n=26$; blue) with presynaptic marker synaptophysin (Syn) (red). Scale bar, $10 \mu \mathrm{m}$.

Both NETO1 and NETO2 have been shown to concentrate on postsynaptic fractions ( $\mathrm{Ng}$ et al., 2009; Zhang et al., 2009; Straub et al., 2011; Tang et al., 2011); however, whether they also localize presynaptically in axons is not known. To investigate their subcellular distribution, HAtagged NETO1 and NETO2 were overexpressed in WT mouse hippocampal neurons using lentiviral vectors. NETO1-HA was detected in MAP2 negative axonal processes (Fig. 2A,B) where it partially colocalized with synaptophysin (Fig. 2C). Also NETO2-HA was detected in MAP2 negative neurites and at axonal synaptophysin puncta; however, the relative axonal intensity of NETO2-HA was significantly lower as compared with NETO1-HA (Fig. 2B, $p=$ 0.011). Both NETO1-HA and NETO2-HA were abundantly transported to MAP2-positive dendrites (Fig. 2A,B).
Together, these data indicate that both Neto1 and Neto2 are expressed in the immature hippocampus but show distinct region specific expression patterns, with Neto 1 being mainly restricted to CA3 and Neto2 showing broader expression in principal neurons within all the hippocampal fields. Both proteins, and in particular NETO1, localize to axons and colocalize with synaptophysin-positive putative vesicle release sites when overexpressed in hippocampal neurons.

\section{NETO1 and NETO2 regulate axonal delivery of KAR subunits}

NETO proteins have been shown to regulate targeting of KARs to postsynaptic sites (Copits et al., 2011; Tang et al., 2011; 2012; Wyeth et al., 2014; Sheng et al., 2015; 
but see Straub et al., 2011), while no corresponding data for axons exist. In the absence of selective antibodies, myc- or flag-tagged recombinant KAR subunits were overexpressed in cultured hippocampal neurons from WT, Neto $1^{-1-}$, and Neto $2^{-1-}$ mice, to study the effect of NETO1 and NETO2 on axonal targeting of KARs. Two C-terminal splice variants of the GluK1, GluK1b and GluK1c, were included in the analysis because previous data indicates that these are differentially transported to axons (Vesikansa et al., 2012). RT-PCR indicated that both Neto1 and Neto2 were expressed in WT neurons under our culture conditions (Fig. 3A).

In WT neurons, all recombinant KAR subunits studied were detected in distal MAP2 negative axons (>150 $\mu \mathrm{m}$ from the soma), with flag-GluK1c and myc-GluK4 showing the highest relative intensity in this region (Fig. 3B,C; see also Vesikansa et al., 2012). When expressed in the $\mathrm{Neto}^{-1-}$ and Neto2 ${ }^{-1-}$ cultures, the labeling of most recombinant KAR subunits in the distal axons was lower as compared with WT neurons, suggesting a generic role for NETOs in KAR targeting. As an exception, the relative axonal intensity of flag-GluK1c in Neto2 ${ }^{-/-}$cultures was comparable to WT, in indicating that the axonal delivery of GluK1c was selectively impaired in the absence of NETO1, but not NETO2 (Fig. 3D,E).

Together, these data suggest that NETO proteins promote trafficking of KAR subunits to axons. Interestingly, axonal delivery of GluK1c, the subunit that is highly expressed in the CA3 pyramidal neurons in the neonatal hippocampus (Vesikansa et al., 2012) was selectively impaired in the $\mathrm{Neto}^{-/-}$, but not $\mathrm{Neto}^{-/-}$, mice.

\section{Tonic activation of presynaptic KARs at immature CA3-CA1 synapses is not observed in the absence of NET01}

To study the role of NETO auxiliary subunits in regulation of presynaptic KAR function, patch clamp recordings of mEPSCs were made from CA1 pyramidal neurons in acute hippocampal slices from neonatal (P4-P6) WT, $\mathrm{Neto}^{-1-}$, and Neto2 ${ }^{-1-}$ mice. At immature CA3-CA1 synapses, presynaptic GluK1 subunit containing KARs are tonically activated by ambient glutamate to inhibit transmitter release (Lauri et al., 2006). Thus, application of a GluK1 selective antagonist enhances transmission, observed as an increase in the frequency of mEPSCs (Lauri et al., 2006; Sallert et al., 2009). As expected, application of ACET (200 nM) led to a significant increase in the mEPSC frequency $(168 \pm 27 \%, n=7, p=0.04)$ but had no effect on their amplitude $(103 \pm 13 \%)$ in the WT slices. A similar increase in mEPSC frequency was also observed in the Neto $2^{-1-}$ slices $(140 \pm 15 \%, n=5, p=0.01)$, in contrast to $\mathrm{Neto}^{-1-}$ slices where ACET had no significant effect on mEPSCs $(83 \pm 19 \%, n=7$; Fig. $4 A, B)$. The basal mEPSC frequency was significantly lower in both Neto $1^{-1-}(p=0.04)$, and Neto $2^{-1-}(p=0.006)$ slices as compared with WT, while the mEPSC amplitude was lower in Neto2 $2^{-/-}(p=0.02)$, but not in $\mathrm{Neto1}^{-/-}$slices (frequency $0.17 \pm 0.02,0.10 \pm 0.01$, and $0.10 \pm 0.01 \mathrm{~Hz}$; amplitude $16.2 \pm 1.2,16.7 \pm 0.8$, and $13.6 \pm 1.1 \mathrm{pA}$ for WT, Neto ${ }^{-1-}$, and Neto $2^{-/-}$, respectively).
The tonic inhibition of glutamate release by GluK1 subunit containing KARs also manifests as facilitation of transmission during high-frequency activity at immature CA3-CA1 synapses (Lauri et al., 2006). Consistent with a loss of tonic KAR activity, facilitation of EPSCs in response to five-pulse $50-\mathrm{Hz}$ afferent stimulation was not observed in CA1 pyramidal neurons in Neto $1^{-1-}$ slices (5th/1st EPSC ratio $1.05 \pm 0.22, n=14$ ), in contrast to WT and Neto $^{-1-}$ slices (WT $2.10 \pm 0.58, n=7$; Neto2 ${ }^{-1-}$ $2.16 \pm 0.46, n=8$; Fig. 4C). No differences in the kinetics of the AMPA EPSCs, evoked by single pulse afferent stimulation, were detected between the genotypes (decay (do-37\% $_{9}$ WT $4.7 \pm 0.74 \mathrm{~ms}, n=6$; Neto ${ }^{-/-} 4.05 \pm 0.72 \mathrm{~ms}, n=8$, $\mathrm{p}_{\mathrm{wT}, \text { Neto1-/- }}=0.44$ and Neto $^{-1-} 3.63 \pm 0.23 \mathrm{~ms}, n=6$, $\mathrm{p}_{\mathrm{WT}, \text { Neto2-1- }}=0.17$; data not shown). These data show that Neto1 deficiency impairs the tonic activation of presynaptic KARs at the immature synapses.

\section{Absence of tonic KAR activity in $\mathrm{Neto1}^{-/-}$slices is due to loss of functional presynaptic KARs}

NETO interaction increases the agonist sensitivity of GluK1 KARs (Fisher, 2015; Li et al., 2016). Thus, the simplest explanation for the loss of tonic KAR activity in the $\mathrm{Neto1}^{-1-}$ slices is that in the absence of NETO1, the presynaptic receptors cannot be activated by the ambient glutamate due to their lower affinity. To address this possibility, we tested the effect of ATPA, a selective agonist for GluK1 KARs (Clarke et al., 1997, Clarke and Collingridge, 2002) on transmission at the CA3-CA1 synapses. ATPA binds to GluK1 with a high affinity and activates GluK1 subunit containing recombinant KARs at submicromolar concentrations in the absence of NETO proteins (Jane et al., 2009). Thus, at $1 \mu \mathrm{M}$ concentration, ATPA is expected to activate GluK1 subunit containing KARs in NETO-deficient neurons. Application of ATPA (1 $\mu \mathrm{M})$ led to a significant decrease in the amplitude of evoked EPSCs in both WT (66 $\pm 7 \%$ of control, $n=6$, $p=0.007$ ) and Neto $2^{-/-}$mice (EPSC amplitude $55 \pm 3 \%$ of control, $n=7, p=0.002$ ), but had no effect on transmission at Neto $1^{-1-}$ slices at P4-P6 (99 $\pm 23 \%, n=$ $9, p=0.1$; Fig. $5 A$ ). Therefore, loss of tonic KAR activity at immature CA3-CA1 synapses of $\mathrm{Neto1}^{-1-}$ mice reflects absence of functional presynaptic KARs and cannot be explained merely by reduced glutamate affinity of GluK1 subunit containing receptors.

The subunit composition as well as the downstream signaling mechanism of the presynaptic KARs changes during development (Sallert et al., 2007; Vesikansa et al., 2012). To study whether NETO1 and NETO2 regulate presynaptic KAR function later on in development, we tested the effect of ATPA at two weeks (P14-P16) old mice, when KARs are no longer tonically active. At this developmental stage, ATPA application resulted in a decrease in the EPSC amplitude also in the $\mathrm{Neto1}^{-1-}$ mice (77 $\pm 7 \%, n=8, p=0.03)$; however, this effect was significantly $(p=0.03)$ smaller to that observed at the WT $(53 \pm 7 \%, n=7$; Fig. $5 B)$. Furthermore, no significant differences in the frequency or amplitude of mEPSCs were detected between the genotypes at P14-P16 [frequency $0.42 \pm 0.05,0.37 \pm 0.04$, and $0.41 \pm 0.04 \mathrm{~Hz}$; 
A

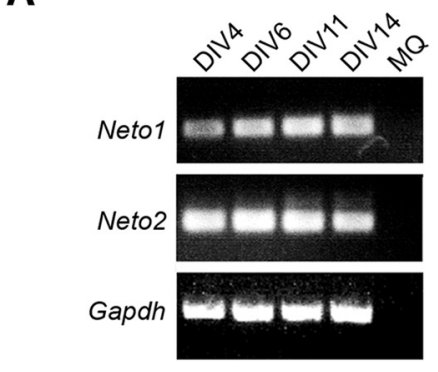

B

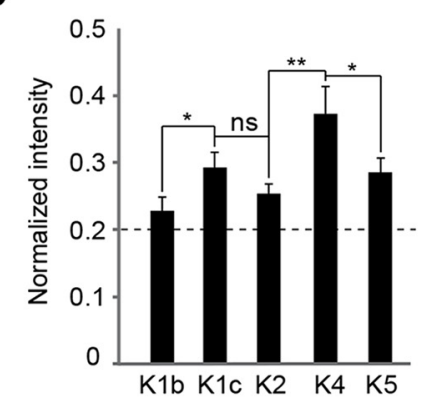

C

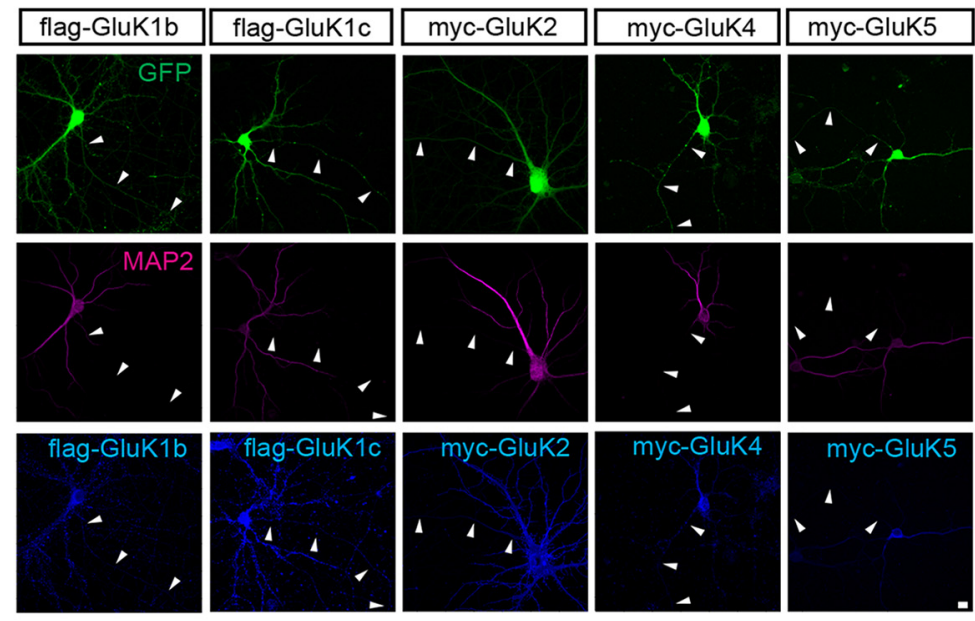

D

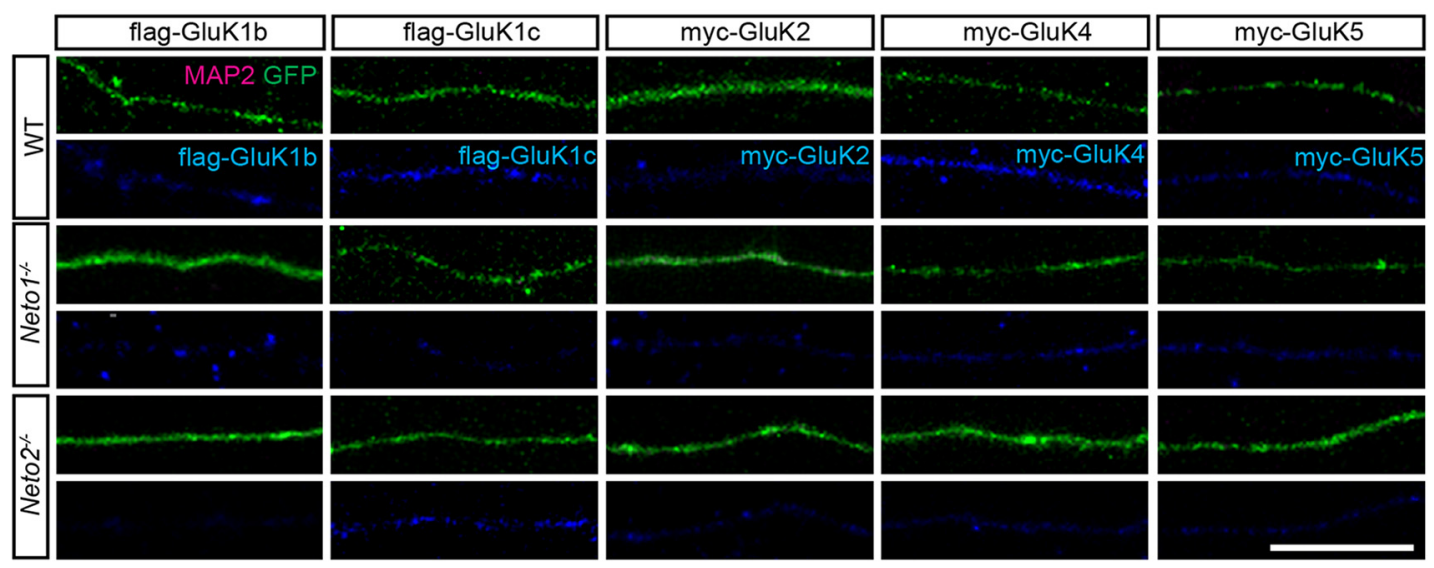

E

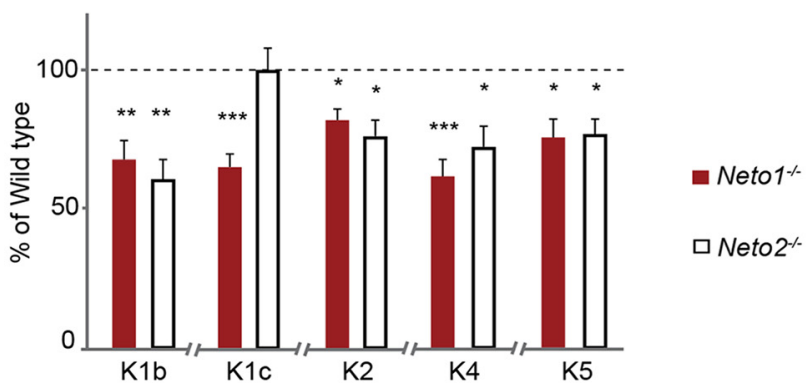

Figure 3. Loss of NETO1 leads to impaired GluK1c delivery to distal axons. A, RT-PCR data depicting Neto1, Neto2, and housekeeping gene Gapdh expression in WT dispersed hippocampal neuron culture throughout the culture period (DIV4, DIV6, DIV11, and DIV14). B, Quantified data on the delivery of recombinant KAR subunits to distal axons in WT hippocampal neurons. K1b: flag-GluK1b ( $n=45)$, K1c: flag-GluK1c $(n=24)$, K2: myc-GluK2 $(n=39)$, K4: myc-GluK4 $(n=30)$, and K5: myc-GluK5 $(n=41)$. Signal intensity in distal axons is normalized to intensity in cell soma. $\boldsymbol{C}$, Example images of WT neurons expressing recombinant flag-GluK1b, flag-GluK1c, myc-GluK2, myc-GluK4, or myc-GluK5 (blue). MAP2 (purple) negative axons are marked with arrowheads. Cell morphology is visualized with GFP (green) expression. Scale bar, $10 \mu \mathrm{m}$. D. Example images illustrating delivery of various recombinant KAR subunits (blue) to distal ( $>150$ $\mu \mathrm{m}$ from soma) MAP2 negative axons in WT, Neto $1^{-1-}$, and Neto2 ${ }^{-1-}$ neurons. Scale bar, $10 \mu \mathrm{m}$. E, Averaged data comparing KAR subunit delivery to WT versus Neto $1^{-1-}$ or Neto $2^{-1-}$ axons. K1b $n=47$ and $n=24, \mathrm{~K} 1 \mathrm{c} n=13$ and $n=29, \mathrm{~K} 2 n=41$ and $n=34, \mathrm{~K} 4$ $n=18$ and $n=22, \mathrm{~K} 5 n=34$ and $n=48$ for Neto $1^{-1-}$ and Neto $2^{-1-}$, respectively. Data are presented as \% of corresponding values in the WT axons. 
A

Wild type

Neto1-

Neto2-

Control
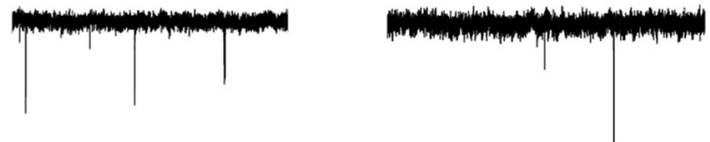

ACET
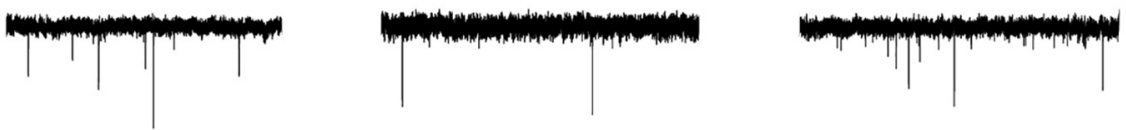

Washout
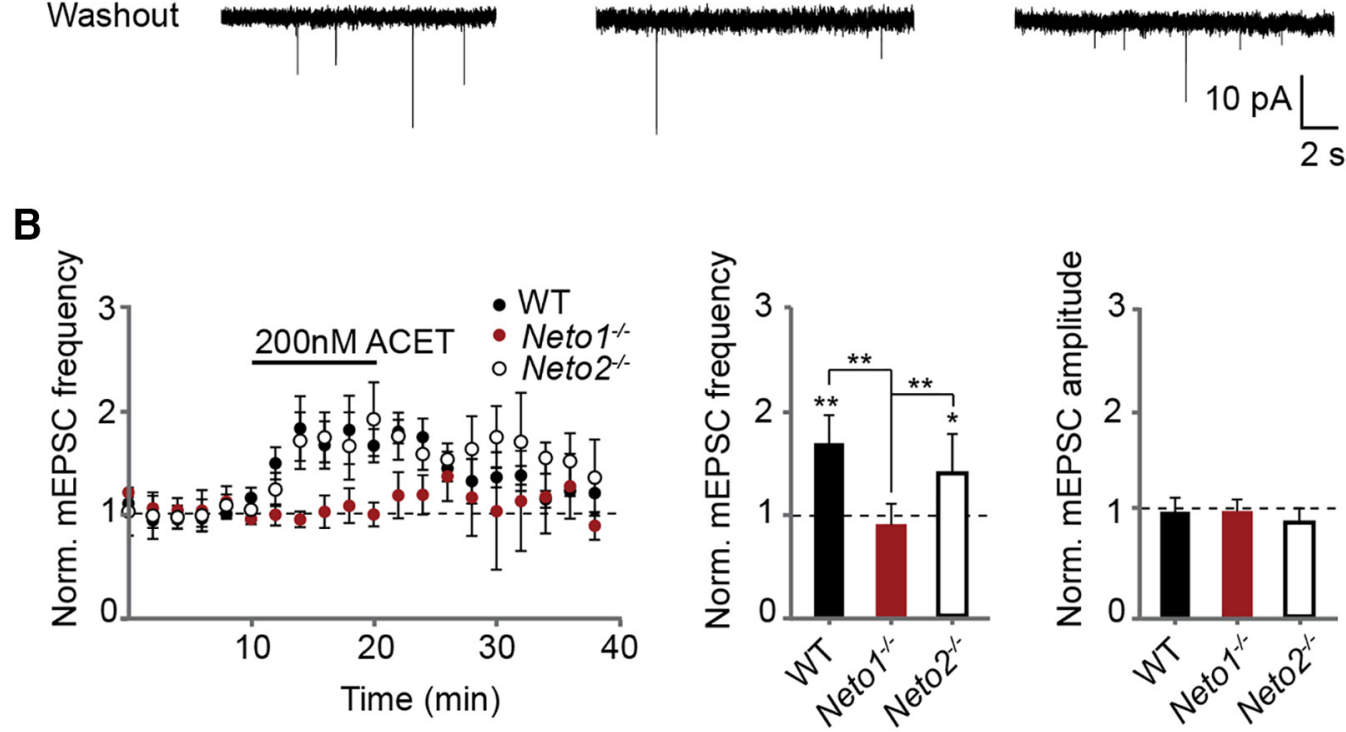

C
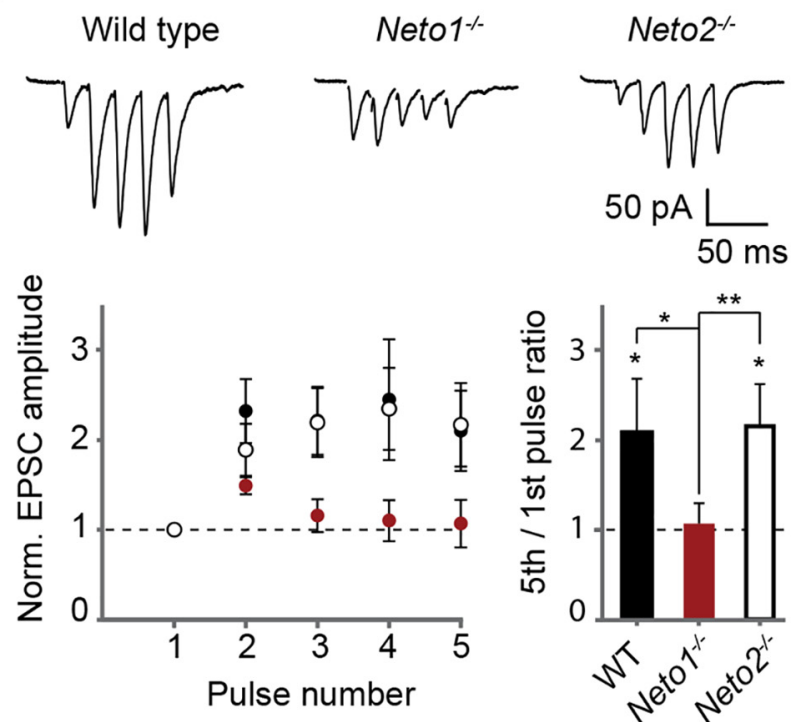

Figure 4. NETO1 is required for tonic activity of KARs at CA3-CA1 synapse in the neonatal hippocampus. $\boldsymbol{A}$, Example traces illustrating recording of mEPSCs from CA1 pyramidal neurons in WT, Neto $1^{-1-}$, and Neto $2^{-1-}$ slices (P5), under control conditions and in the presence of ACET (200 nM). $\boldsymbol{B}$, time-course plots and averaged data demonstrating the effect of ACET (200 nM) on mEPSC frequency in WT $(n=7)$ and Neto $2^{-1-}(n=5)$, and Neto $1^{-1-}(n=7)$ slices (P4-P6). C, Example traces and pooled data demonstrating short-term facilitation of EPSCs in response to five-pulse $50-\mathrm{Hz}$ stimulation in WT $(n=7)$ and Neto2 ${ }^{-1-}(n=8)$, but not in Neto $1^{-1-}$ $(n=14)$ slices (P4-P6). 
A

P5 - P6
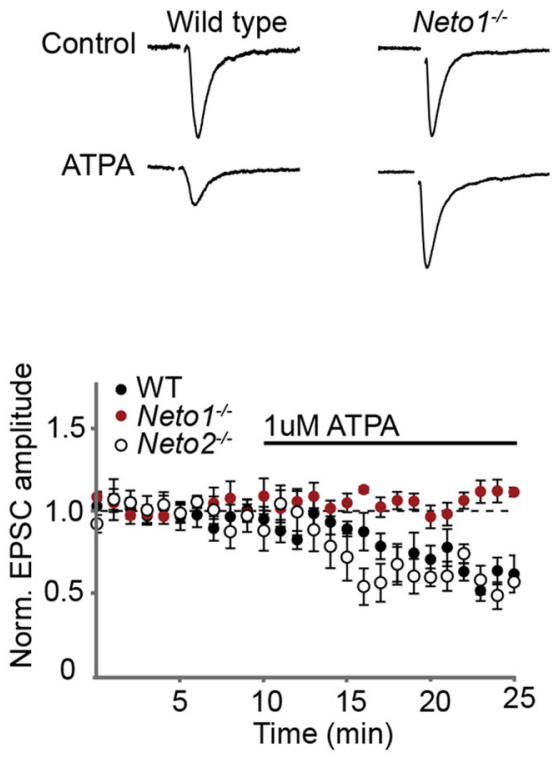

C
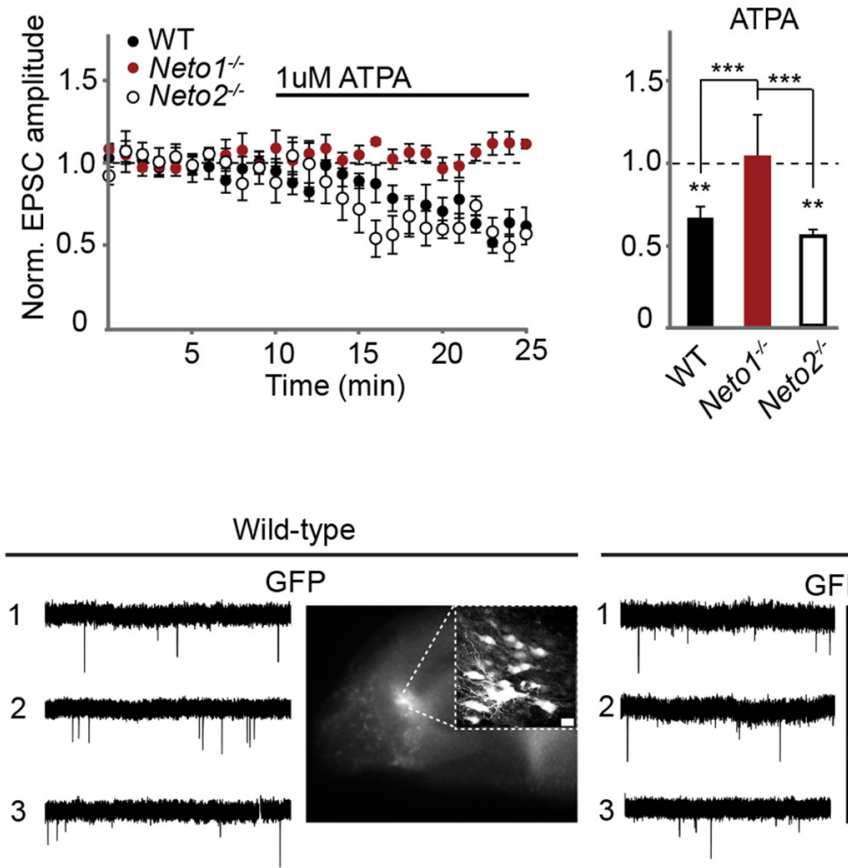

B

P14 - P16
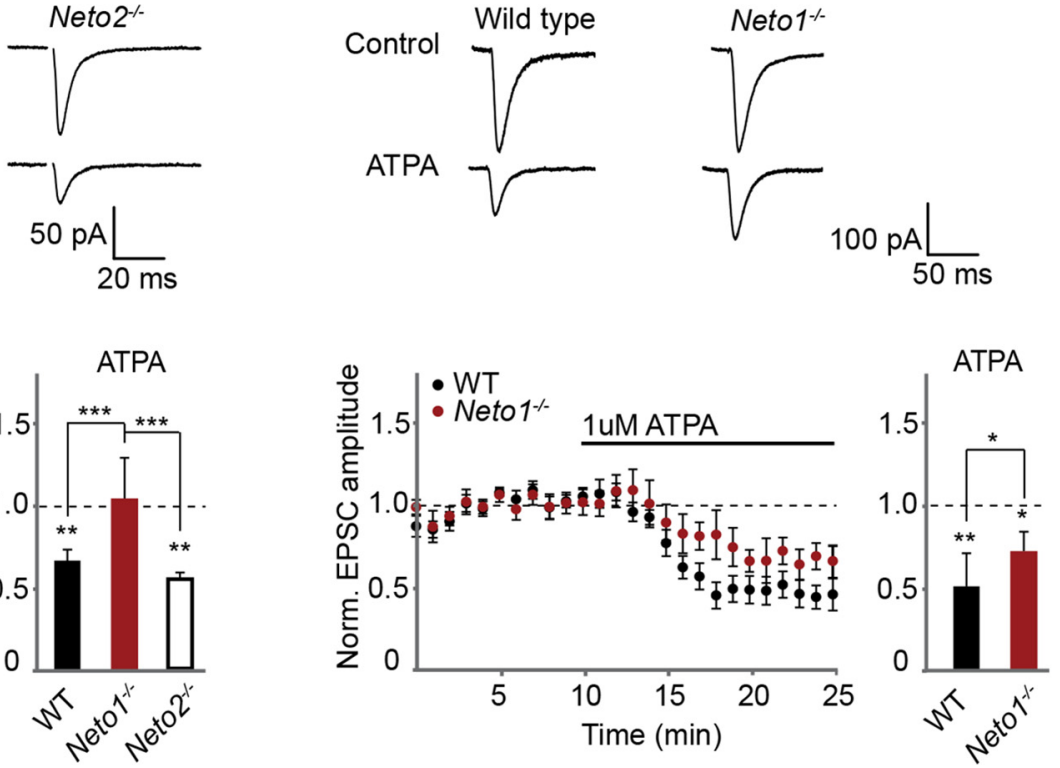

$20 \mathrm{pA} \frac{\mathrm{Lss}}{4 \mathrm{~ms}}$

D

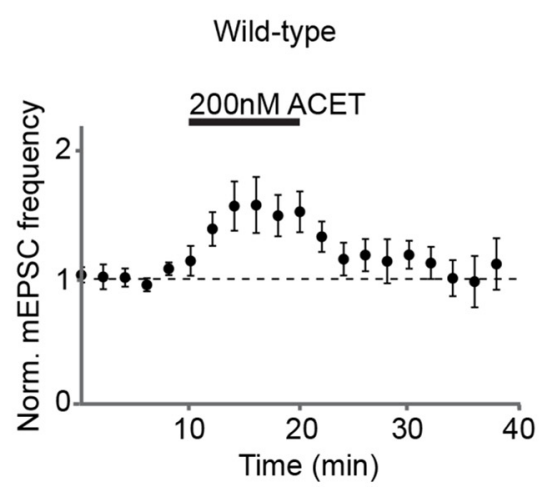

E

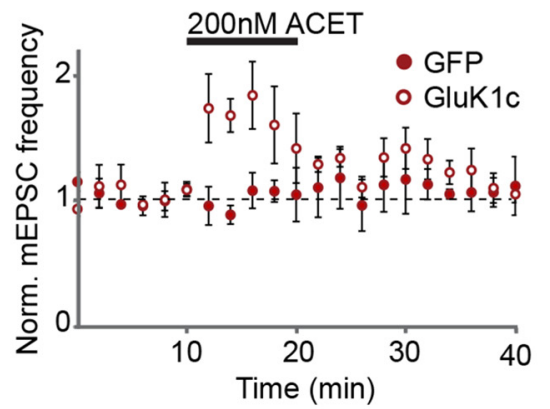

Neto $1^{1 / 2}$

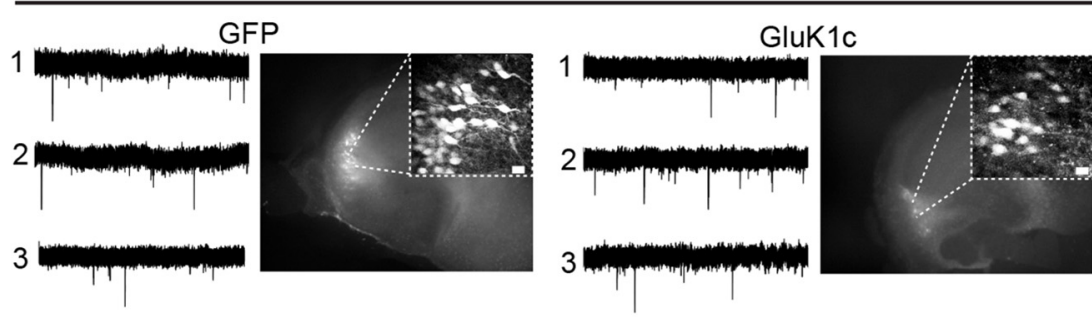

F

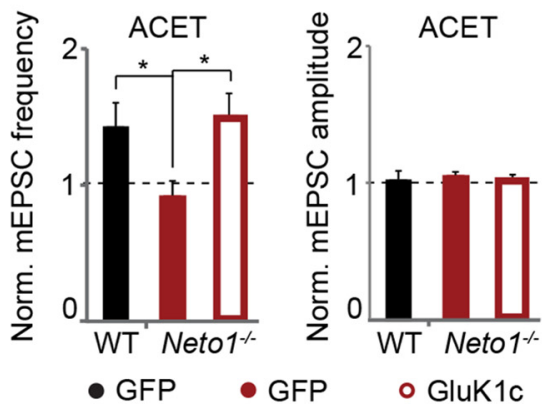

Figure 5. NETO1 deficiency leads to loss of functional presynaptic KARs at immature CA3-CA1 synapses that is rescued with GluK1c overexpression in the area CA3. A, Example traces and pooled data showing that ATPA (1 $\mu \mathrm{M})$ decreases synaptic transmission at CA3-CA1 synapse in WT $(n=6)$ and Neto2 ${ }^{-1-}(n=7)$, but not in Neto1 ${ }^{-1-}(n=9)$ acute slices (P4-P6). B, Example traces and pooled data showing the effect of ATPA $(1 \mu \mathrm{M})$ on EPSCs in two week old (P14-P16) WT $(n=7)$ and Neto $1^{-1-}(n=8)$ acute slices. C, Example traces of mEPSCs recorded from CA1 pyramidal neurons in WT and Neto $1^{-1-}$ organotypic cultures expressing GFP or GluK1c in CA3 pyramidal layer, under control conditions (trace 1), in the presence of ACET (200 nM; trace 2), and during washout (trace 3). Images show the GFP or GluK1c/GFP expression in the CA3 pyramidal layer in the corresponding cultures (scale bar, $20 \mu \mathrm{m}$ ). $\boldsymbol{D}$, Time-course plot demonstrating the effect of ACET $(200 \mathrm{nM})$ on mEPSC frequency in WT organotypic cultures expressing GFP (WT $n=7)$ in area CA3. $\boldsymbol{E}$, Time-course plot demonstrating the effect of ACET $(200 \mathrm{nM})$ on mEPSC frequency in Neto $1^{-/-}$organotypic cultures expressing GFP $(n=5)$ or GluK1c $(n=4)$ in area CA3. $\boldsymbol{F}$, Pooled data for the experiments depicted in $\boldsymbol{D}, \boldsymbol{E}$. 
amplitude $16.6 \pm 0.7,16.4 \pm 0.8$, and $17.8 \pm 0.4 \mathrm{pA}$ for WT $(n=14)$, Neto $^{-1-}(n=10)$, and Neto2 ${ }^{-1-}(n=10)$, respectively; data not shown]. These data suggest that NETO1 deficiency affects presynaptic KAR function predominantly during early postnatal development, when GluK1 subunit is highly expressed at CA3 pyramidal neurons and presynaptic KARs are physiologically activated.

NETO deficiency reduced the axonal delivery of KAR subunits but did not completely block it. Therefore, we reasoned that also NETO independent mechanisms for KAR targeting exist and overexpression of KAR subunits could rescue KAR levels in NETO-deficient axons. To test this possibility, we made organotypic cultures from WT and NETO1-deficient mice and used lentiviral vectors to overexpress GluK1c or GFP in the CA3 pyramidal cells. Patch clamp recordings of mEPSCs were made from CA1 pyramidal neurons at DIV5-DIV7. Similar to the acute slices from neonatal hippocampus, ACET (200 nM) application in the GFP-expressing WT slice cultures was associated with an increase in the frequency of mEPSCs (143 $\pm 17 \%, n=7, p=0.03$ ) but no change in their amplitude (102 $\pm 6 \%)$. ACET application had no effect on mEPSC frequency in GFP-expressing Neto $1^{-1-}$ cultures $(92 \pm 10 \%, n=5)$, while a significant increase in mEPSC frequency was observed in Neto $1^{-1-}$ cultures where GluK1c was overexpressed in the CA3 pyramidal cells $(148 \pm 0.18 \%, n=4, p=0.03$; Fig. $5 C-F)$. Thus, overexpression of GluK1c in the CA3 pyramidal neurons was sufficient to rescue the tonic presynaptic KAR activity in the $\mathrm{Neto}^{-1-}$ slices. Together, these data support the conclusion that the loss of tonic KAR activity in the Neto $1^{-1-}$ mice is due to loss of axonal GluK1 subunit containing KARs.

\section{Absence of NETO1, but not NETO2, affects presynaptic differentiation in hippocampal neurons}

The obtained results show that $\mathrm{Neto}^{-1-}$ mice lack presynaptic KAR activity at the CA3-CA1 circuit and suggest this is due to impaired axonal targeting of GluK1 subunit containing KARs. Presynaptic KARs have been implicated in development of the synaptic connectivity between CA3 and CA1 pyramidal neurons (Lauri et al., 2006; Sallert et al., 2009; Vesikansa et al., 2007, 2012; Sakha et al., 2016). Therefore, we went on to examine the density of synaptophysin puncta in WT, Neto $1^{-1-}$, and Neto $2^{-/-}$axons, focusing only on MAP2 negative processes with no visible postsynaptic (MAP2 positive) contacts. The mean density of synaptophysin puncta in GFPexpressing Neto $1^{-1-}(77 \pm 7 \%$ of WT, $n=36, p=0.04)$, but not Neto2 ${ }^{-\prime-}(108 \pm 9 \%$ of WT, $n=28)$, axons was significantly lower as compared with WT (Fig. 6).

In WT and Neto2 ${ }^{-1-}$ neurons, overexpression of flagGluK1c increased the density of synaptophysin puncta in isolated axons (WT $136 \pm 12 \%, n=19, p=0.007$; Neto2 ${ }^{-/-} 135 \pm 11 \%, n=31, p=0.01$ ) as previously shown (Sakha et al., 2016). In Neto ${ }^{-1-}$ neurons, however, this increase was significantly larger $(179 \pm 26 \%, n=19$, $p<0.001$ ), resulting in similar density of the synaptophysin puncta as in GluK1c-expressing WT axons. In contrast, overexpression of flag-GluK1b or myc-GluK2 had no significant effect on the density of axonal synaptophysin puncta in any of the genotypes (Fig. $6 A, B$ ). These data suggest that the lack of axonal KARs, likely containing the GluK1c subunit, impairs presynaptic differentiation in the Neto $1^{-1-}$ neurons.

\section{NETO1 regulates development of functional connectivity in the CA3-CA1 circuit}

To address the physiologic significance of NETO1 in the development of CA3-CA1 circuitry, hippocampal slices from WT and Neto $1^{-1-}$ mice were cultured on microelectrode array (MEA) probes and the spontaneous network activity was recorded at DIV2 and DIV6 using channels located at the CA3 and CA1 pyramidal cell regions. During this period in culture, the network activity patterns in WT slices gradually transformed from asynchronous firing (DIV2) to highly correlated bursting activity that ultimately takes the form of ictal-like epileptiform bursts (DIV6 onwards; data not shown). Thus, in the WT slices, the mean frequency of population spikes and bursts (defined as at least three events with interspike-interval of $<10 \mathrm{~ms}$ ) increased during development in vitro both in areas CA3 and CA1 (Fig. 7A,B). In the Neto $1^{-1-}$ slices, the mean spike frequency was lower as compared with WTs at both developmental stages in CA1 and in CA3 (Fig. 7A,B). At DIV2, the mean frequency of bursts in $\mathrm{Neto}^{-1-}$ cultures was not different from the WTs. However, as there was no significant increase in bursts during development, the burst frequency in the NETO1-deficient slices was significantly lower as compared with WTs at DIV6 (Fig. 7A,B).

The observed differences in the overall activity patterns might be mediated by a variety of neural mechanisms operating at different cell types within the hippocampal network. To focus on the CA3-CA1 connectivity, we went on to analyze temporal correlation in spiking activities of the CA3 and CA1 neuronal populations. Correlation in the CA3-CA1 population spiking activity was assessed with spike time tiling coefficient (STTC $\mathrm{CAB}, \mathrm{CA} 1_{1}$; Cutts and Eglen, 2014), which is independent on the differences in basal firing frequency. In WT cultures, STTC $\mathrm{CA3}, \mathrm{CA} 1_{\text {increased }}$ significantly during development from DIV2 to DIV6 $(n=$ $11, p=0.031$; Fig. 7A,C). In Neto $1^{-1-}$ cultures, $\mathrm{STTC}_{\mathrm{CA} 3, \mathrm{CA} 1}$ was significantly lower than in WT cultures already at DIV2, and more evidently at DIV6 (Fig. 7C). Importantly, in $\mathrm{Neto1}^{-1-}$ cultures STTC $\mathrm{CA3}, \mathrm{CA} 1_{\text {did not }}$ increase during development, suggesting that NETO1 affects development of synchrony between CA3-CA1 neuronal populations.

Given that synaptogenesis in Neto $1^{-1-}$ axons was dependent on GluK1c levels, we went on to test whether overexpression of GluK1c in the presynaptic CA3 neurons would rescue the observed defect in synchronization of CA3-CA1 circuit in the Neto $1^{-1-}$ cultures. Lentiviral overexpression of GluK1c in the CA3 pyramidal cells in Neto $1^{-1-}$ slice cultures was associated with a higher frequency of spikes and bursts as compared with controls at DIV6 (GFP-expressing or nonmanipulated CA3 neurons in the same slices; Fig. $7 D, E)$. Interestingly, $S T_{T C} C_{C A 3, C A 1}$ for GluK1c-expressing Neto $1^{-1-}$ CA3 neuron populations was significantly higher as compared with GFP-expressing 
A
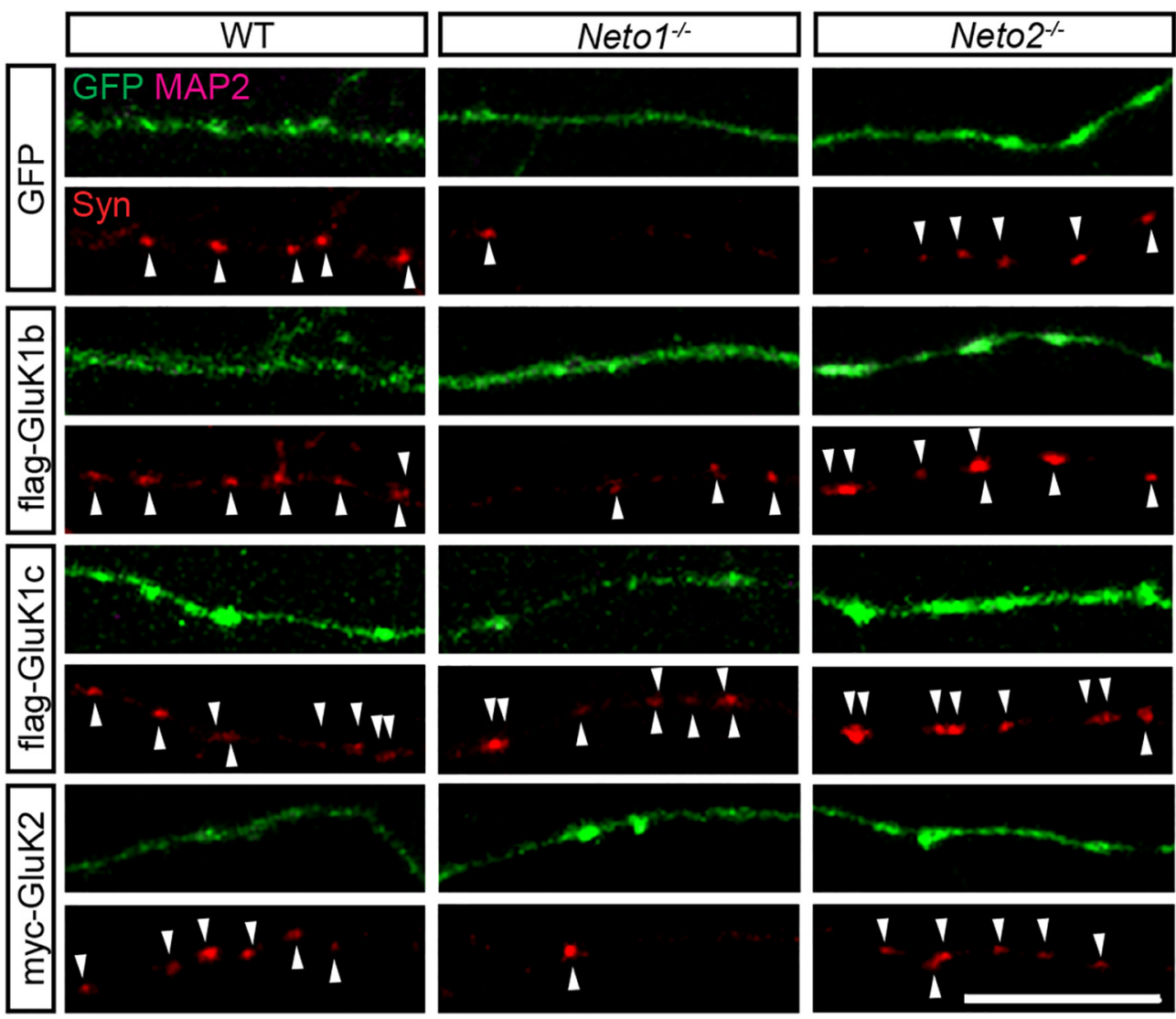

B

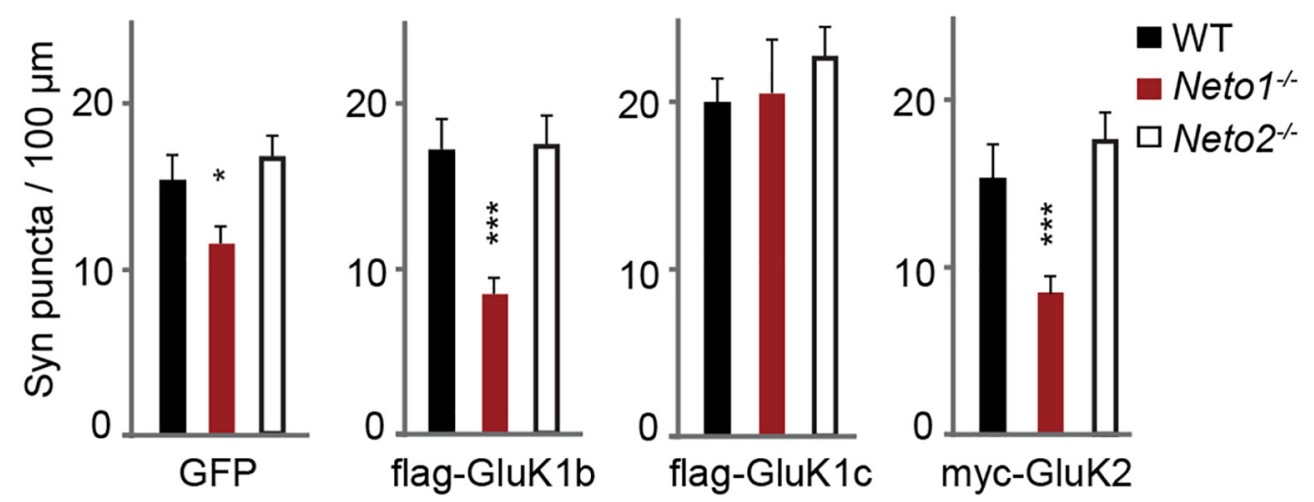

Figure 6. Loss of axonal GluK1c in Neto $1^{-1-}$ neurons results in reduced density of synaptophysin immunopositive (Syn) puncta. $\boldsymbol{A}$, Example images of Syn puncta (red) in MAP2 negative WT, Neto $1^{-1-}$, and Neto2 $2^{-1-}$ axons with lentiviral expression of GFP, GFP + flag-GluK1b, GFP + flag-GluK1c, or GFP + myc-GluK2. For clarity, the blue channel with flag/myc staining is not shown. Scale bar, $10 \mu \mathrm{m}$. B, Quantification of the Syn puncta (red) density in the three genotypes with lentiviral expression of GFP (WT $n=31$; Neto ${ }^{-1-}$ $n=36 ;$ Neto2 $\left.^{-\prime-} n=28\right)$, GFP + flag-GluK1b (WT $n=28 ;$ Neto $^{-1-} n=29 ;$ Neto $\left.^{-/-} n=24\right)$, GFP + flag-GluK1c (WT $n=28 ;$ Neto $1^{-/-}$ $n=19 ;$ Neto2 $^{-/-} n=31$ ), or GFP + myc-GluK2 (WT $n=40 ;$ Neto1 $^{-1-} n=30 ;$ Neto2 $^{-1-} n=27$ ).

controls, and similar to WT slices (Fig. 7F). These data suggest that elevated expression of KARs in presynaptic neurons can fully rescue the defect in functional development of the CA3CA1 connectivity in the Neto $1^{-1-}$ slice cultures.

\section{Discussion}

NETO proteins were identified as auxiliary subunits for KARs originally in 2009 (Zhang et al., 2009; Tang et al.,
2011); however, our knowledge on their physiologic significance in the brain is still limited. In particular, very little is known on the functions of NETOs in the developing brain where KARs are widely expressed. Here, we show that NETO1 affects development of the hippocampal CA3-CA1 circuit via regulating axonal KARs. In the absence of NETO1, functional presynaptic KARs at the nascent connections are 
A
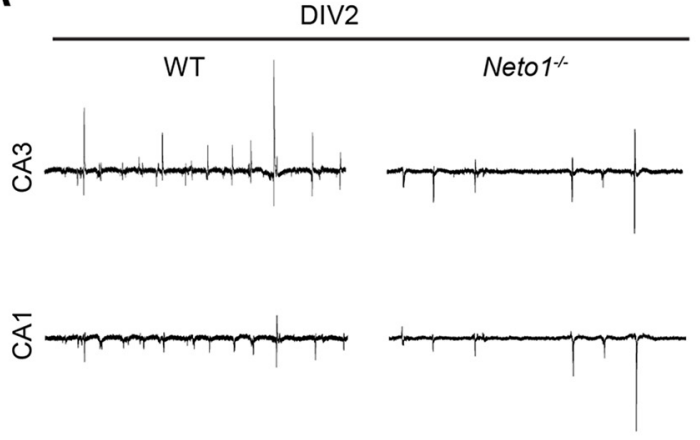

B

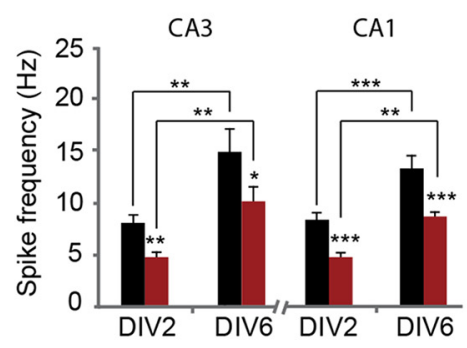

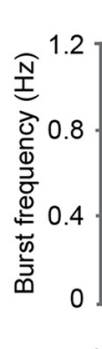

CA3

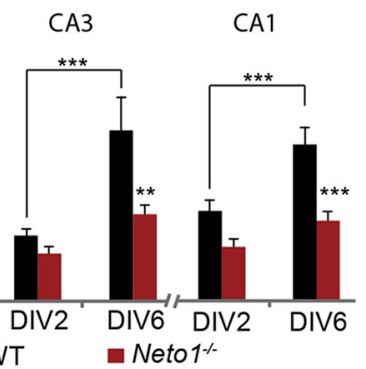

DIV6
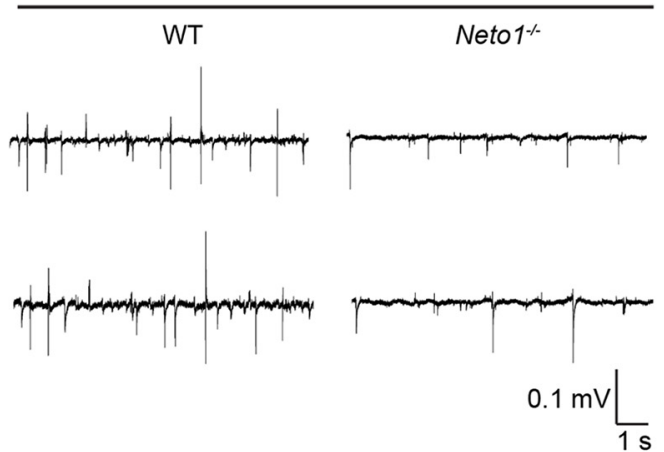

D

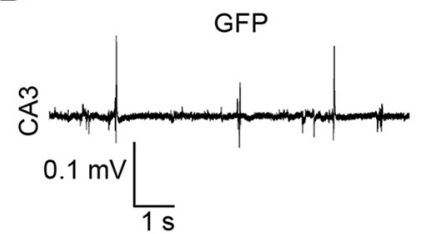

C

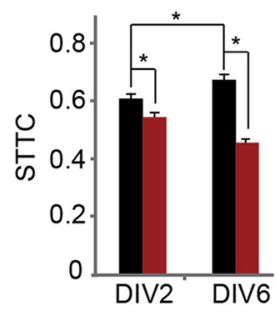

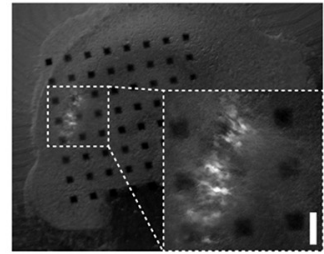

E

GluK1c
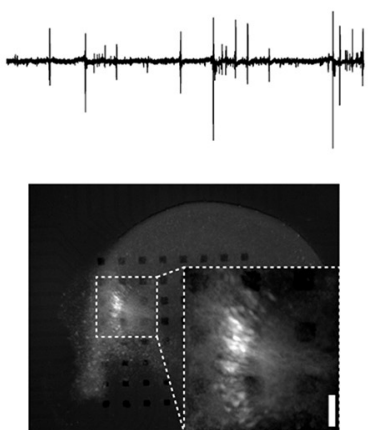

F
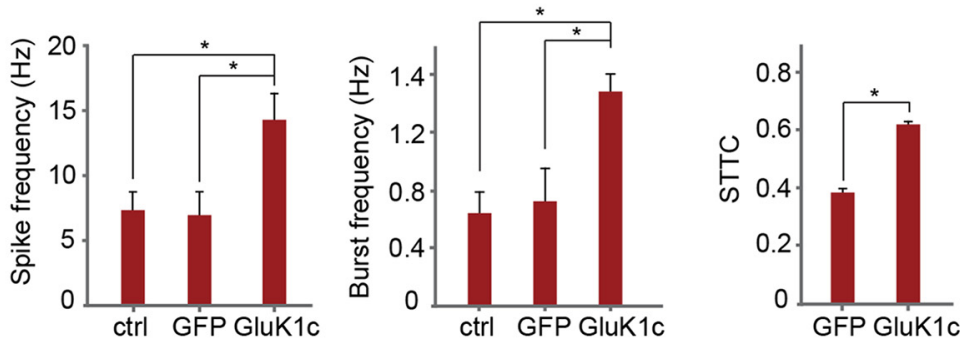

Figure 7. Neto1-dependent axonal targeting of GluK1c is required for developmental synchronization of the CA3-CA1 circuit. $\boldsymbol{A}$, Example traces illustrating spontaneous activity in CA3 and CA1 regions of WT and Neto $1^{-1-}$ hippocampal slices cultured on MEA probes at DIV2 and DIV6. B, Quantification of spike frequency and burst frequency in WT (DIV2 $n=12$, DIV6 $n=11$ ) and Neto $1^{-/-}$ (DIV2 $n=12$, DIV6 $n=13$ ) slices. Data are averaged from at least two channels located in CA3 and in CA1 pyramidal regions/slice.

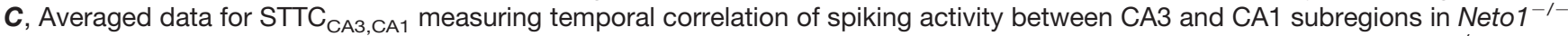
$(n=12)$ and WT $(n=11)$ slices. $\boldsymbol{D}$, Images showing GFP and GluK1c/GFP expression in CA3 principal cells in Neto ${ }^{-1-}$ slices. Example traces demonstrate the activity in the virally transduced region of the corresponding slice cultures at DIV6. Scale bar, 150 $\mu \mathrm{m}$. $\boldsymbol{E}$, Quantification of spike frequency and burst frequency for nonmanipulated (ctrl, $n=7)$, GFP $(n=7)-$, or GluK1c/GFP $(n=$ 8)-expressing CA3 cell populations in Neto $1^{-1-}$ slices at DIV6. F, Analysis of the STTC CA3,CA1 $_{\text {in Neto } 1^{-1-}}$ (DIV6) slices were the CA3 cell populations have been virally transduced to express GFP $(n=7)$ or GluK1c/GFP $(n=8)$. 
lost, leading to impaired synaptogenesis. Thus, in addition to the previously characterized roles of NETO proteins in modulating postsynaptic KARs, we here demonstrate that NETO1 regulates presynaptic KARs in developing hippocampal networks and thereby contributes to wiring of the CA3-CA1 circuitry.

\section{NETO proteins promote axonal recruitment of KARs}

Although presynaptic functions for KARs have been described in various areas of the brain, the mechanisms governing axonal targeting of KARs are not well understood. Our data using epitope tagged KAR subunits in cell cultures shows that NETO1 and NETO2 deficiency impairs axonal targeting of most KAR subunits to a similar extent, except for GluK1c whose axonal targeting was selectively reduced in $\mathrm{Neto}^{-1-}$, but not $\mathrm{Neto}^{-1-}$, neurons.

The observed generic and subunit-dependent effects of NETOs on KAR targeting resembles what has been previously shown for TARP and cornichon families of AMPA auxiliary subunits. These auxiliary proteins act as chaperones regulating assembly and ER export of AMPA receptors (Jackson and Nicoll, 2011; Straub and Tomita, 2011), a mechanism that could also explain the subunit independent effects of NETOs on KARs. Regarding axonal delivery of GluK1c splice variant, the specific regulation by NETO1, but not NETO2, may be achieved in different ways. For instance, GluK1c contains a C-terminal 29 amino acid insert that is not present in any of the other KAR subunits, which could mediate splice-variant specific protein interaction(s). Such proteins could affect NETOGluK1c interaction directly or indirectly, for example by recruitment of second messengers enabling covalent modification. Indeed, it was recently shown that mutation of putative C-terminal phosphorylation site in NETO proteins disrupt NETO-dependent postsynaptic trafficking of GluK1 (Sheng et al., 2015). When overexpressed in cell cultures, both NETO1 and NETO2 were detected in axons, supporting the hypothesis that NETO1 associates with the KARs complex to directly regulate its axonal and presynaptic targeting. Unfortunately, in our hands, the available antibodies were not selective enough to study the subcellular localization of native NETO proteins in intact tissue to resolve whether they are localized at presynaptic terminals in the neonatal or adult brain.

\section{NETO1 is required for tonic presynaptic KAR activity at immature synapses}

Synaptic transmission in neonatal NETO1-deficient slices was completely insensitive to GluK1 selective drugs, which are specific for presynaptic KARs at WT CA3-CA1 synapses (Lauri et al., 2006). Furthermore, frequency-dependent facilitation of transmission, attributed to tonic inhibition of release probability by presynaptic KARs at immature synapses (Lauri et al., 2006) was not observed in $\mathrm{Neto}^{-1-}$ slices, together indicating that NETO1 is critical for immature-type presynaptic KAR function.

GluK1c and GluK4 are the subunits previously implicated in tonic presynaptic KAR activity at the immature synapses (Vesikansa et al., 2012). Thus, GluK1c splice variant is coexpressed in the CA3 pyramidal cells with the subunit GluK4 during the first postnatal week temporally coinciding with the tonic KAR activity, after which its expression is rapidly downregulated (Vesikansa et al., 2012). Our ISH and RT-qPCR analysis indicates that both Neto 1 and Neto2 mRNA are expressed in CA3 pyramidal neurons in the neonatal hippocampus. Both NETO1 and NETO2 affected axonal targeting of KARs and we cannot rule out the possibility that some of the NETO2 functions in the knockout mice are compensated for. Nevertheless, the loss of presynaptic KAR function at $\mathrm{Neto1}^{-1-} \mathrm{CA3}-$ CA1 synapses during the time GluK1c is expressed at CA3 pyramidal neurons corresponds well to the finding that NETO1 specifically regulates axonal recruitment of GluK1c in cultured neurons. Later on in development (P14) when GluK1c expression is already downregulated, presynaptic KARs could be pharmacologically activated to depress synaptic transmission also at the NETO1deficient slices, although the effect was smaller as compared with the WTs. Finally, overexpression of GluK1c in the CA3 pyramidal neurons was able to rescue the presynaptic KAR function at CA3-CA1 synapses in the NETO1-deficient slices. Together, these findings show that NETO1 deficiency leads to loss of presynaptic KAR function particularly at immature synapses, where GluK1c is endogenously expressed. NETO1 promotes but is not absolutely required for presynaptic KARs function, as its dependence on NETO1 is reduced on KAR overexpression and during development.

NETO1 deficiency reduced the axonal levels of recombinant GluK1c to $\sim 60 \%$ of the control level, raising a question whether such a modest reduction in axonal targeting can explain the complete loss of functional presynaptic KAR at immature synapses. It is possible that the observed effects of NETOs on recombinant KARs underestimate the reliance of native KARs on auxiliary subunits, as the mechanisms responsible for subcellular segregation of KARs may be overloaded during elevated expression, leading to nonphysiological compartmentalization (Fièvre et al., 2016). On the other hand, compartmentalization of KARs in dissociated cultured neurons may be weak as compared with intact tissue, where diverse extracellular interactions take place and may regulate synaptic recruitment of KARs directly or indirectly (Fièvre et al., 2016; Matsuda et al., 2016). While our data show that NETO proteins promote axonal delivery of KAR subunits, it does not define the extent by which NETO1 affects targeting of endogenous KARs in native tissue environment. As such, we cannot exclude the possibility that NETO1 regulates presynaptic KAR function also by additional mechanisms, for example by contributing to the assembly of the signaling complex that mediates the effects of KARs on glutamate release or by altering the biophysical properties by which the receptors are activated by ambient glutamate.

\section{NETO proteins and synaptogenesis}

Axonal KARs have been implicated in development and maturation of synaptic connectivity both in cultured neurons (Tashiro et al., 2003; Sakha et al., 2016) as well as in 
intact circuitry (Lauri et al., 2006; Vesikansa et al., 2012). Consistent with the loss of presynaptic KAR function, we observed that the density of axonal Syn puncta was reduced in $\mathrm{Neto}^{-/-}$, but not Neto2 ${ }^{-/-}$, neurons and fully rescued by GluK1c overexpression. These data support the hypothesis that NETO1 promotes presynaptic development during the time of intense synaptogenesis and circuit refinement via regulation of axonal GluK1 subunit containing KARs. Since our analysis of presynaptic puncta was done on isolated axons, these findings further confirm that axonal GluK1c containing KAR affects presynaptic differentiation directly, in the absence of postsynaptic contact. Intriguingly, in contrast to the present results in isolated axons, GluK2 overexpression led to a strong increase in Syn puncta in axons that grow in bundles in microfluidic grooves (Sakha et al., 2016). While the exact mechanism explaining this difference remains unknown, these results call for better understanding of the mechanisms and consequences of the GluK1 versus GluK2 extracellular interactions (Matsuda et al., 2016, Sheng et al., 2017).

Interestingly, although the density of presynaptic release sites was compromised selectively in the Neto $1^{-1-}$ axons, the basal mEPSC frequency at immature CA1 pyramidal cells was significantly lower in both Neto $1^{-1-}$ and $\mathrm{Neto}^{-/-}$slices as compared with WT. The mEPSC frequency reflects the number and release probability $(\mathrm{Pr})$ of functional synaptic inputs. Based on the lower facilitation of EPSCs during $50-\mathrm{Hz}$ stimulation, mean $\mathrm{Pr}$ in the Neto $1^{-1-}$ mice is higher as compared with WTs, consistent with the loss of tonic KAR mediated inhibition of release (Lauri et al., 2006). Yet, the higher $\operatorname{Pr}$ in the Neto $1^{-1-}$ mice would compensate for any effects of a lower synapse density on mEPSC frequency. In Neto $2^{-1-}$, but not $\mathrm{Neto}^{-1-}$, slices, the mEPSC amplitude was lower as compared with the WT, pointing to a postsynaptic phenotype. NETO2 can target KARs to postsynaptic sites at CA1 neurons (Copits et al., 2011; Sheng et al., 2015), which might influence synaptogenesis (Marchal and Mulle, 2004; Lanore et al., 2012; Petrovic et al., 2017) via a different but complementary mechanism. In addition, NETO2 might influence synaptic maturation via KAR independent mechanisms, for example via the recently described interaction with the KCC2 (Ivakine et al., 2013) implicated in regulation of spine density (Li et al., 2007). The effects of NETO deficiency on mEPSCs were only observed during early postnatal development, indicating that any dependency of synaptogenesis on NETO proteins is not absolute and can be compensated by other mechanisms during development.

\section{NETO1 influences developmental synchronization of neuronal populations}

The significance of the NETO1-dependent presynaptic KAR activity on the development of CA3-CA1 circuitry was further studied at the network level. To that end, NETO1-deficient slices were cultured on MEA probes allowing functional properties of the neuronal network to be monitored through development in vitro. During the first days in vitro, activity of CA3 and CA1 neuronal pop- ulations became increasingly synchronized, in parallel with an increase in synaptic connectivity in these cultures (De Simoni et al., 2003; Chiappalone et al., 2007). In the absence of NETO1, synchronization between CA3 and CA1 firing activities was significantly impaired. This phenotype was fully rescued by GluK1c expression at CA3 neurons, suggesting an important role of NETO1-dependent axonal KARs in functional development of the network.

Apart from the reduced synchronization, we observed reduced excitability (i.e. population spike frequency) in the NETO1-deficient neurons while GluK1c overexpression in the CA3 pyramidal neurons robustly increased CA3 population firing rate. Higher charge transfer through postsynaptic KARs is expected to amplify spike transmission due to their integrative properties on transmission (Frerking and Ohliger-Frerking 2002; Sachidhanandam et al., 2009; Pinheiro et al., 2013). Thus, the reduced firing rate in the absence of NETO1 likely reflects loss of postsynaptic KARs in the pyramidal neurons (Straub et al., 2011), leading to reduced postsynaptic integration and excitability. In cultured hippocampal neurons, a critical level of excitability is required for synchronization to take place (Penn et al., 2016). In Neto $1^{-/-}$slices; however, some network bursts were generated already at DIV2, suggesting that the level of excitability was not limiting the entrainment of neurons to synchronous populations. In addition to pyramidal neurons, NETO1 expression was also detected at GABAergic interneurons, which have a critical role in network oscillations and synchrony. However, the reduced synchrony between CA3-CA1 neuronal populations in the Neto $1^{-1-}$ slices was fully rescued by overexpression of GluK1c at the CA3 pyramidal neurons, suggesting that weaker synaptic connectivity between CA3-CA1 neuronal populations due to loss of presynaptic KARs significantly contributed to disrupted synchrony in the NETO1deficient slices.

There is strong evidence suggesting that correlation between neuronal spike times is vital for organization of the neural circuits during development (Xu et al., 2011). Despite the defect in developmental synchronization of the network, NETO1-deficient mice have no gross abnormalities in the hippocampal morphology, but show a defect in hippocampus-dependent learning paradigms ( $\mathrm{Ng}$ et al., 2009). The lack of striking morphologic phenotype is not surprising given the high capacity of developing neuronal networks for compensatory plasticity (Huupponen et al., 2007; Yin and Yuan, 2015). However, it is possible that such compensatory mechanisms mask vulnerability that can be later on manifested, for example as an increased susceptibility for neurologic disorders (Charlesworth et al., 2016).

\section{References}

Akgül G, McBain CJ (2016) Diverse roles for ionotropic glutamate receptors on inhibitory interneurons in developing and adult brain. J Physiol 594:5471-5490. CrossRef

Anderson WW, Collingridge GL (2007) Capabilities of the WinLTP data acquisition program extending beyond basic LTP experimental functions. J Neurosci Methods 162:346-356. CrossRef Medline Chan HL, Lin MA, Wu T, Lee ST, Tsai YT, Chao PK (2008) Detection of neuronal spikes using an adaptive threshold based on the 
max-min spread sorting method. J Neurosci Methods 172:112121. CrossRef

Charlesworth P, Morton A, Eglen SJ, Komiyama NH, Grant SG (2016) Canalization of genetic and pharmacological perturbations in developing primary neuronal activity patterns. Neuropharmacology 100:47-55. CrossRef Medline

Chiappalone M, Vato A, Berdondini L, Koudelka-Hep M, Martinoia S (2007) Network dynamics and synchronous activity in cultured cortical neurons. Int J Neural Syst 17:87-103. CrossRef Medline

Clarke VR, Ballyk BA, Hoo KH, Mandelzys A, Pellizzari A, Bath CP, Thomas J, Sharpe EF, Davies CH, Ornstein PL, Schoepp DD, Kamboj RK, Collingridge GL, Lodge D, Bleakman D (1997) A hippocampal GluR5 kainate receptor regulating inhibitory synaptic transmission. Nature 389:599-603. CrossRef Medline

Clarke VR, Collingridge GL (2002) Characterisation of the effects of ATPA, a GLU(K5) receptor selective agonist, on excitatory synaptic transmission in area CA1 of rat hippocampal slices. Neuropharmacology 42:889-902. Medline

Clarke VR, Molchanova SM, Hirvonen T, Taira T, Lauri SE (2014) Activity-dependent upregulation of presynaptic kainate receptors at immature CA3-CA1 synapses. J Neurosci 34:16902-16916. CrossRef Medline

Copits BA, Swanson GT (2012) Dancing partners at the synapse: auxiliary subunits that shape kainate receptor function. Nat Rev Neurosci 13:675-686. CrossRef Medline

Copits BA, Robbins JS, Frausto S, Swanson GT (2011) Synaptic targeting and functional modulation of GluK1 kainate receptors by the auxiliary neuropilin and tolloid-like (NETO) proteins. J Neurosci 31:7334-7340. CrossRef Medline

Cutts CS, Eglen SJ (2014) Detecting pairwise correlations in spike trains: an objective comparison of methods and application to the study of retinal waves. J Neurosci 34:14288-14303. CrossRef Medline

De Simoni A, Griesinger CB, Edwards FA (2003) Development of rat CA1 neurones in acute versus organotypic slices: role of experience in synaptic morphology and activity. J Physiol 550:135-147. CrossRef Medline

Fièvre S, Carta M, Chamma I, Labrousse V, Thoumine O, Mulle C (2016) Molecular determinants for the strictly compartmentalized expression of kainate receptors in CA3 pyramidal cells. Nat Commun 7:12738. CrossRef Medline

Fisher JL (2015) The auxiliary subunits Neto1 and Neto2 have distinct, subunit-dependent effects at recombinant GluK1- and GluK2-containing kainate receptors. Neuropharmacology 99:471480. CrossRef Medline

Frerking M, Ohliger-Frerking P (2002) AMPA receptors and kainate receptors encode different features of afferent activity. J Neurosci 22:7434-7443. Medline

Hanse E, Taira T, Lauri S, Groc L (2009) Glutamate synapse in developing brain: an integrative perspective beyond the silent state. Trends Neurosci 32:532-537. CrossRef Medline

Huupponen J, Molchanova SM, Taira T, Lauri SE (2007) Susceptibility for homeostatic plasticity is down-regulated in parallel with maturation of the rat hippocampal synaptic circuitry. J Physiol 581:505-514. CrossRef

Ivakine EA, Acton BA, Mahadevan V, Ormond J, Tang M, Pressey JC, Huang MY, Ng D, Delpire E, Salter MW, Woodin MA, Mclnnes RR (2013) Neto2 is a KCC2 interacting protein required for neuronal $\mathrm{Cl}$ - regulation in hippocampal neurons. Proc Natl Acad Sci USA 110:3561-3566. CrossRef Medline

Jackson AC, Nicoll RA (2011) The expanding social network of ionotropic glutamate receptors: TARPs and other transmembrane auxiliary subunits. Neuron 70:178-199. CrossRef Medline

Jane DE, Lodge D, Collingridge GL (2009) Kainate receptors: pharmacology, function and therapeutic potential. Neuropharmacology 56:90-113. CrossRef Medline

Lanore F, Labrousse VF, Szabo Z, Normand E, Blanchet C, Mulle C (2012) Deficits in morphofunctional maturation of hippocampal mossy fiber synapses in a mouse model of intellectual disability. J Neurosci 32:17882-17893. CrossRef
Lauri SE, Bortolotto ZA, Bleakman D, Ornstein PL, Lodge D, Isaac JT, Collingridge GL (2001) A critical role of a facilitatory presynaptic kainate receptor in mossy fiber LTP. Neuron 32:697-709. Medline

Lauri SE, Segerstråle M, Vesikansa A, Maingret F, Mulle C, Collingridge GL, Isaac JT, Taira T (2005) Endogenous activation of kainate receptors regulates glutamate release and network activity in the developing hippocampus. J Neurosci 25:4473-4484. CrossRef Medline

Lauri SE, Vesikansa A, Segerstråle M, Collingridge GL, Isaac JT, Taira T (2006) Functional maturation of CA1 synapses involves activity-dependent loss of tonic kainate receptor-mediated inhibition of glutamate release. Neuron 50:415-429. CrossRef Medline

Lerma J, Marques JM (2013) Kainate receptors in health and disease. Neuron 80:292-311. CrossRef Medline

Li H, Khirug S, Cai C, Ludwig A, Blaesse P, Kolikova J, Afzalov R, Coleman SK, Lauri S, Airaksinen MS, Keinänen K, Khiroug L, Saarma M, Kaila K, Rivera C (2007) KCC2 interacts with the dendritic cytoskeleton to promote spine development. Neuron 56:1019-1033. CrossRef Medline

Li B, Rex E, Wang H, Qian Y, Ogden AM, Bleakman D, Johnson KW (2016) Pharmacological Modulation of GluK1 and GluK2 by NETO1, NETO2, and PSD95. Assay Drug Dev Technol 14:131143. CrossRef Medline

Marchal C, Mulle C (2004) Postnatal maturation of mossy fibre excitatory transmission in mouse CA3 pyramidal cells: a potential role for kainate receptors. J Physiol 561:27-37. CrossRef Medline

Matsuda K, Budisantoso T, Mitakidis N, Sugaya Y, Miura E, Kakegawa W, Yamasaki M, Konno K, Uchigashima M, Abe M, Watanabe I, Kano M, Watanabe M, Sakimura K, Aricescu AR, Yuzaki M (2016) Transsynaptic modulation of kainate receptor functions by C1q-like proteins. Neuron 90:752-767. CrossRef Medline

Michishita M, Ikeda T, Nakashiba T, Ogawa M, Tashiro K, Honjo T, Doi K, Itohara S, Endo S (2003) A novel gene, Btcl1, encoding CUB and LDLa domains is expressed in restricted areas of mouse brain. Biochem Biophys Res Commun 306:680-686. Medline

Michishita M, Ikeda T, Nakashiba T, Ogawa M, Tashiro K, Honjo T, Doi K, Itohara S, Endo S (2004) Expression of Btcl2, a novel member of Btcl gene family, during development of the central nervous system. Brain Res Dev Brain Res 153:135-142. CrossRef Medline

Ng D, Pitcher GM, Szilard RK, Sertié A, Kanisek M, Clapcote SJ, Lipina T, Kalia LV, Joo D, McKerlie C, Cortez M, Roder JC, Salter MW, Mclnnes RR (2009) Neto1 is a novel CUB-domain NMDA receptor-interacting protein required for synaptic plasticity and learning. PLoS Biol 7:e41. CrossRef Medline

Palacios-Filardo J, Aller MI, Lerma J (2016) Synaptic targeting of kainate receptors. Cereb Cortex 26:1464-1472. CrossRef Medline

Penn Y, Segal M, Moses E (2016) Network synchronization in hippocampal neurons. Proc Natl Acad Sci USA 113:3341-3346. CrossRef Medline

Petrovic MM, Viana da Silva S, Clement JP, Vyklicky L, Mulle C, González-González IM, Henley JM (2017) Metabotropic action of postsynaptic kainate receptors triggers hippocampal long-term potentiation. Nat Neurosci 20:529-539. CrossRef Medline

Pinheiro PS, Mulle C (2008) Presynaptic glutamate receptors: physiological functions and mechanisms of action. Nat Rev Neurosci 9:423-436. CrossRef Medline

Pinheiro PS, Lanore F, Veran J, Artinian J, Blanchet C, Crépel V, Perrais D, Mulle C (2013) Selective block of postsynaptic kainate receptors reveals their function at hippocampal mossy fiber synapses. Cereb Cortex 23:323-331. CrossRef Medline

Sachidhanandam S, Blanchet C, Jeantet Y, Cho YH, Mulle C (2009) Kainate receptors act as conditional amplifiers of spike transmission at hippocampal mossy fiber synapses. J Neurosci 29:50005008. CrossRef Medline

Sakha P, Vesikansa A, Orav E, Heikkinen J, Kukko-Lukjanov TK, Shintyapina A, Franssila S, Jokinen V, Huttunen HJ, Lauri SE (2016) Axonal kainate receptors modulate the strength of efferent 
connectivity by regulating presynaptic differentiation. Front Cell Neurosci 10:3. CrossRef Medline

Sallert M, Malkki H, Segerstråle M, Taira T, Lauri SE (2007) Effects of the kainate receptor agonist ATPA on glutamatergic synaptic transmission and plasticity during early postnatal development. Neuropharmacology 52:1354-1365. CrossRef Medline

Sallert M, Rantamäki T, Vesikansa A, Anthoni H, Harju K, YliKauhaluoma J, Taira T, Castren E, Lauri SE (2009) Brain-derived neurotrophic factor controls activity-dependent maturation of CA1 synapses by downregulating tonic activation of presynaptic kainate receptors. J Neurosci 29:11294-11303. CrossRef Medline

Schmitz SK, Hjorth JJ, Joemai RM, Wijntjes R, Eijgenraam S, de Bruijn P, Georgiou C, de Jong AP, van Ooyen A, Verhage M, Cornelisse LN, Toonen RF, Veldkamp WJ (2011) Automated analysis of neuronal morphology, synapse number and synaptic recruitment. J Neurosci Meth 195:185-193. CrossRef

Segerstråle M, Juuri J, Lanore F, Piepponen P, Lauri SE, Mulle C, Taira $T$ (2010) High firing rate of neonatal hippocampal interneurons is caused by attenuation of afterhyperpolarizing potassium currents by tonically active kainate receptors. J Neurosci 30:6507-6514.

Sheng N, Shi YS, Lomash RM, Roche KW, Nicoll RA (2015) Neto auxiliary proteins control both the trafficking and biophysical properties of the kainate receptor GluK1. Elife 4:e11682. CrossRef

Sheng N, Shi YS, Nicoll RA (2017) Amino-terminal domains of kainate receptors determine the differential dependence on Neto auxiliary subunits for trafficking. Proc Natl Acad Sci USA 114:1159-1164. CrossRef Medline

Straub C, Tomita S (2011) The regulation of glutamate receptor trafficking and function by TARPs and other transmembrane auxiliary subunits. Curr Opin Neurobiol 22:488-495. CrossRef Medline

Straub C, Hunt DL, Yamasaki M, Kim KS, Watanabe M, Castillo PE, Tomita S (2011) Distinct functions of kainate receptors in the brain are determined by the auxiliary subunit Neto1. Nat Neurosci 14: 866-873. CrossRef Medline

Tang M, Ivakine E, Mahadevan V, Salter MW, Mclnnes RR (2012) Neto2 interacts with the scaffolding protein GRIP and regulates synaptic abundance of kainate receptors. PLoS One 7:e51433. CrossRef Medline
Tang M, Pelkey KA, Ng D, Ivakine E, McBain CJ, Salter MW, McInnes RR (2011) Neto1 is an auxiliary subunit of native synaptic kainate receptors. J Neurosci 31:10009-10018. CrossRef Medline

Tashiro A, Dunaevsky A, Blazeski R, Mason CA, Yuste R (2003) Bidirectional regulation of hippocampal mossy fiber filopodial motility by kainate receptors: a two-step model of synaptogenesis. Neuron 38:773-784. Medline

Tomita S, Castillo PE (2012) Neto1 and Neto2: auxiliary subunits that determine key properties of native kainate receptors. J Physiol 590:2217-2223. CrossRef Medline

Vesikansa A, Sakha P, Kuja-Panula J, Molchanova S, Rivera C, Huttunen HJ, Rauvala H, Taira T, Lauri SE (2012) Expression of GluK1c underlies the developmental switch in presynaptic kainate receptor function. Sci Rep 2:310. CrossRef Medline

Vesikansa A, Sallert M, Taira T, Lauri SE (2007) Long-term activation of kainate receptor subunit GluR5 increases mEPSC frequency in the hippocampal slice cultures. J Physiol 583:145-157. CrossRef

Wilkinson DG, Green J (1990) In situ hybridization and the threedimensional construction of serial sections. In: Postimplantation mammalian embryos (Copp AJ, Cockroft DL eds). Oxford: IRL Press.

Wyeth MS, Pelkey KA, Petralia RS, Salter MW, McInnes RR, McBain CJ (2014) Neto auxiliary protein interactions regulate kainate and NMDA receptor subunit localization at mossy fiber-CA3 pyramidal cell synapses. J Neurosci 34:622-628. CrossRef Medline

Xu HP, Furman M, Mineur YS, Chen H, King SL, Zenisek D, Zhou ZJ, Butts DA, Tian N, Picciotto MR, Crair MC (2011) An instructive role for patterned spontaneous retinal activity in mouse visual map development. Neuron 70:1115-1127. CrossRef Medline

Yin J, Yuan Q (2015) Structural homeostasis in the nervous system: a balancing act for wiring plasticity and stability. Front Cell Neurosci 8:439. CrossRef Medline

Zhang W, St-Gelais F, Grabner CP, Trinidad JC, Sumioka A, Morimoto-Tomita M, Kim KS, Straub C, Burlingame AL, Howe JR, Tomita S (2009) A transmembrane accessory subunit that modulates kainate-type glutamate receptors. Neuron 61:385-396. CrossRef Medline 